$1-1-1977$

\title{
Changes in meat consumption and expenditures for West Virginia, 1973-75
}

John P. Kuehn

Follow this and additional works at: https://researchrepository.wvu.edu/ wv_agricultural_and_forestry_experiment_station_bulletins

\section{Digital Commons Citation}

Kuehn, John P., "Changes in meat consumption and expenditures for West Virginia, 1973-75" (1977). West Virginia Agricultural and Forestry Experiment Station Bulletins. 655.

https://researchrepository.wvu.edu/wv_agricultural_and_forestry_experiment_station_bulletins/556 @ WVU. It has been accepted for inclusion in West Virginia Agricultural and Forestry Experiment Station Bulletins by an authorized administrator of The Research Repository @ WVU. For more information, please contact ian.harmon@mail.wvu.edu. 
Uletin 655

arch 1977

est Virginia University

gricultural and

corestry

xperiment Station
Changes in Meat Consumption and Expenditures for West Virginia 1973-75
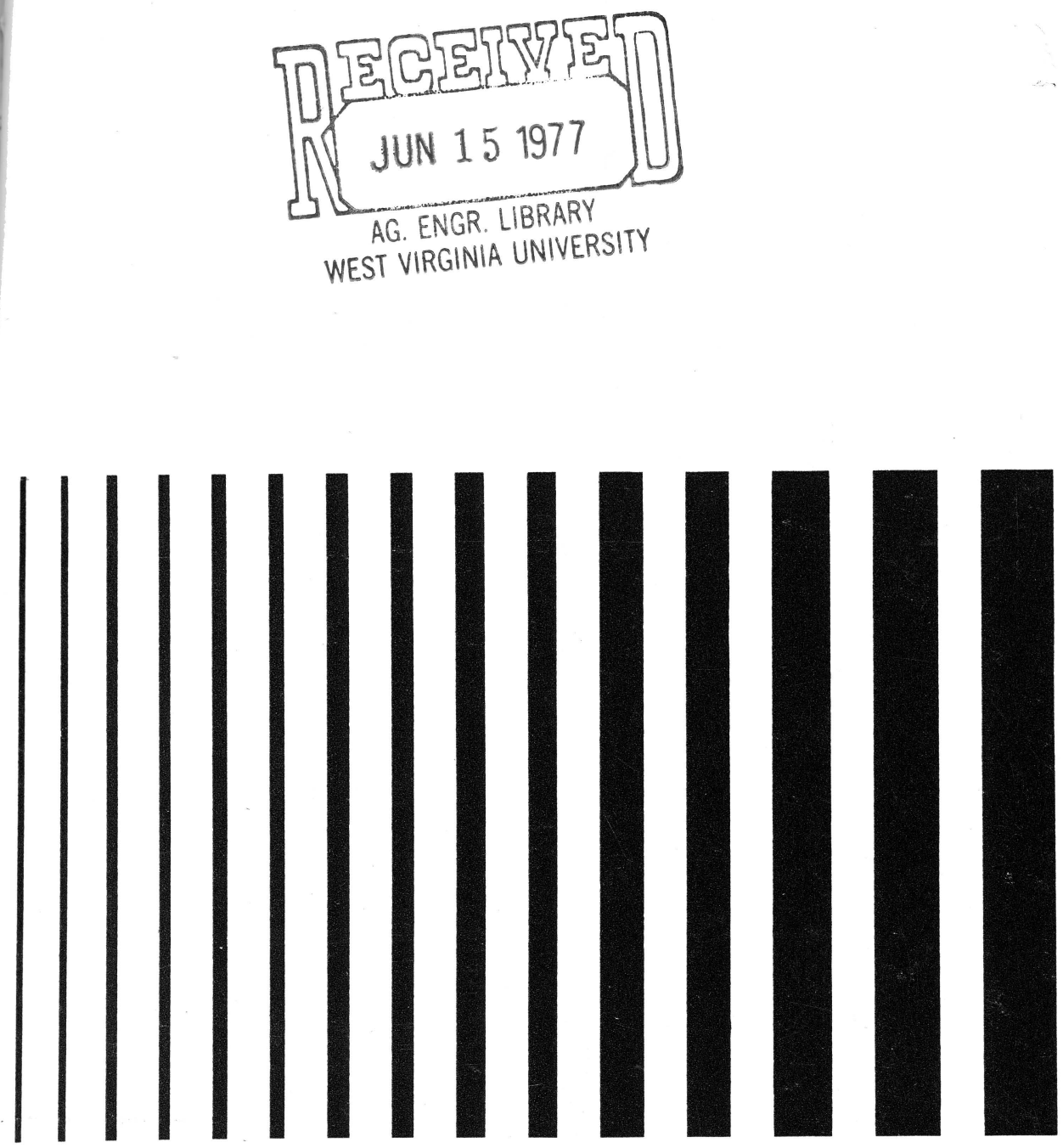

S127

. El

no. 655 
Blank Page in Original Bulletin 


\section{SUMMARY}

The overall objectives of this study were to determine the nature of changes in the consumption of beef, pork, poultry, and seafood between July 1973 and July 1975. There were marked fluctuations in the U. S. economy during this period, with highly inflationary price increases, along with high levels of unemployment and decreases in national productivity.

To determine consumption patterns, a mail questionnaire was administered to stratified random samples of households in West Virginia in July 1973 and again in July 1975. Each sample was representative of the household population of the state and was stratified, on the basis of population per square mile, into "rural," "middle," or "urban" population areas.

Generally, the survey showed that consumption per person in West Virginia increased, except for areas classified as "rural." Meat expenditures increased, except for "rural" areas. U.S. prices for all meats increased, but at a rate below the consumer price index. West Virginia per capita income increased at a slightly higher rate than the consumer price index, which was especially true for "rural" areas. Expenditures on meat declined as a proportion of gross personal income because income increased at a greater rate than meat prices. The proportion of real income spent for meats decreased for all population areas.

Although West Virginians were consuming more, they spent less of their earnings on meat in 1975 than in 1973 due to the prevailing economic conditions. And although more goods and services were purchased by the average West Virginian in 1975 than in 1973 a smaller proportion of these goods were meats. Also, of all the meats purchased, the real proportion of poultry and seafood became larger and the real proportion of beef and pork declined. "Rural" areas of the state were an exception to this generalization. Purchases of zach of the four meats accounted for a smaller proportion of real income in 1975 than in 1973. 
THE AUTHOR

John P. Kuehn is Associate Agricultural Economist.

\author{
West Virginia University \\ Agricultural and Forestry Experiment Station \\ College of Agriculture and Forestry \\ Dale W. Zinn, Director \\ Morgantown
}




\section{Changes in Meat Consumption and Expenditures for West Virginia, 1973-75}

\section{JOHN P. KUEHN}

In July 1973 a mail survey was administered to a sample of households in West Virginia to examine meat consumption characteristics and the socioeconomic factors which affect them. The survey was repeated in 1975 to determine the nature and magnitude of any changes. ${ }^{1}$ This bulletin is based on the 1975 study.

The national economy was subjected to some significant fluctuations between 1973 and 1975 . The seasonally adjusted index of industrial production $(1967=100)$ decreased from 126.7 in July 1973 to 110.8 (preliminary) in July $1975 .^{2}$ This 12.5 percent decrease in production combined with an increase in the rate of unemployment from 4.7 to 8.4 percent during the same period signalled one of the most severe recessions since that of the 1930s. ${ }^{3}$

Unlike previous periods, the recessionary factors were accompanied by highly inflationary price changes. The Consumer Price Index increased by 22.3 percent between July 1973 and July 1975 (Figure 1). ${ }^{4}$ Retail food prices increased 26.8 percent and, more specifically, the index of meat, poultry, and fish prices increased 19 percent. $^{5}$

Although total personal income increased about 20 percent during the period, real income decreased 2.2 percent. $^{6}$ Decreasing real incomes, coupled with higher prices, could possibly cause consumption to decrease. However, U.S.

${ }^{1}$ Kuehn, John P. and James W. Bias, Beef and Pork Consumption in West Virginia, WVU Ag. Exp. Sta. Bull. 637, March 1975; Kuehn, John P. and James W. Bias, Poultry, Seafood, and Lunch Meat Consumption in West Virginia, WVU Ag. Exp. Sta. Bull. 638, March 1975.

${ }^{2}$ Survey of Current Business, Volume 54, No. 6, Bureau of Economic Analysis, U.S. Dept. of Commerce, July, 1974, p. S-4 and Survey of Current Business, Volume 55, No. 8, Bureau of Economic Analysis, U.S. Dept. of Commerce, August 1975, p. S-4.

\footnotetext{
${ }^{3}$ Ibid., p. S-13

${ }^{4}$ Ibid. p. S-8

${ }^{5}$ Ibid.

${ }^{6}$ Ibid., p. S-3
} 
per capita beef consumption increased almost 13 percent. ${ }^{7}$ Pork consumption did decrease nine percent between the third quarter of 1973 and the third quarter of $1975 ;^{8}$ per capita poultry and fish consumption also declined by 1.9 and 4.3 percent, respectively, during this time. ${ }^{9}$

\section{OBJECTIVES}

The specific objectives of this study were:

1. To estimate the one-week per capita consumption of beef, pork, poultry, and seafood and the per capita expenditures for each by households in West Virginia (July 1975).

2. To compare these estimates to associated socioeconomic characteristics of households in the state, and

3. To determine the nature and magnitude of changes occurring between July 1973 and July 1975 with respect to the above objectives.

\section{SAMPLING PROCEDURE}

For both the 1973 study and the 1975 study the state's 55 counties were divided into three classes on the basis of the 1970 population per square mile. Counties having a population of 20 or fewer people per square mile were classified as "rural." Nine counties containing approximately 6.5 percent of the population fell into this category. Those counties with more than 20 people per square mile but fewer than 100 were classified as "middle." The 31 middle counties contain 53 percent of the state's population. The counties having a population of 100 or more people per square mile were classified as "urban" counties.

A representative sample of counties was selected at random from each county classification group. A total of 18 counties was selected and divided as follows: three "rural," ten "middle," and five "urban." The number of randomly selected counties in each category was proportional to the share of the state's population in that category. Two individual random samples were selected, one for the 1973 study and one for the 1975 study.

After the counties in each classification group were randomly selected, the names of potential respondents were chosen randomly from area telephone directories. At least 400 consumer responses were required to assure a 95 percent level of confidence that the sample was representative of the population. ${ }^{10}$

${ }^{7}$ Livestock and Meat Situation, LMS-205, ERS, USDA, Oct. 1975, p. 24

8 Ibid.

${ }^{9}$ National Food Situation, Bulletin NFS-153, ERS, USDA, Sept. 1975, p. 16.

${ }^{10}$ New York State Division of Housing, A Method of Employing Sampling Techniques in Housing Survey, New York, New York State Division of Housing, Sept. 1948, p. 136. 


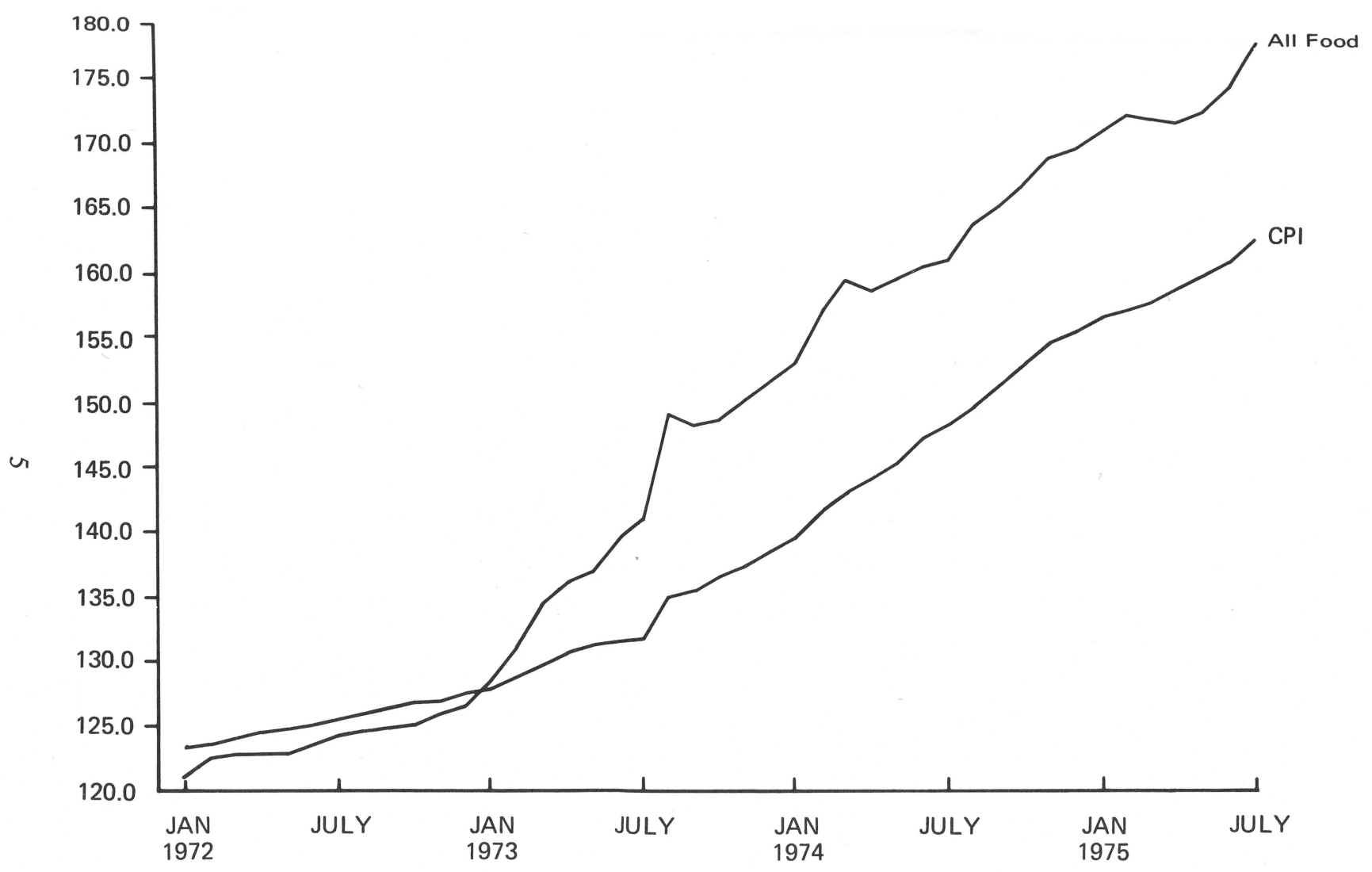

Figure 1. Consumer Price Index and All Food Price Index, 1967=100. (Source: National Food Situation, February 1973, November 1974, and September 1975.) 
In the 1973 study, 2,000 questionnaires were mailed to potential respond. ents. These questionnaires were distributed to the three different classes of counties according to the proportion of population that each class contained. Accordingly, 130 questionnaries were sent to potential respondent "rural" counties, 1,060 to "middle" counties, and 810 to "urban" counties. Since the initial level response was inadequate in several of the counties, a follow-up letter was mailed to those counties with poor rates of response. The follow-up letter was mailed three weeks after the questionnaire to each of the households in the original sample, with instructions to disregard the letter if they had already responded. Of the 2,000 questionnaires sent out in 1973, 450 were returned in a useable form.

In the 1975 study 3,000 questionnaires (copy in Appendix) were sent out in the same manner, assuming that a larger number of questionnaires would preclude the need for a follow-up letter. In this study, 195 questionnaires were sent to "rural" counties, 1,590 to "middle" counties, and 1,215 were sent to "urban" counties. Returns, however, were so inadequate that a similar follow-up letter was sent to each of the 3,000 potential respondents; 420 useable questionnaires were finally returned.

For both studies the questionnaires were mailed in July. They were addressed to the family member most responsible for meat purchasing. Each was asked to report on the consumption of the various meats by his or her household during a seven-day period, either preceeding or following the day the questionnaire was received.

\section{CHANGES IN QUANTITIES PURCHASED AND EXPENDITURES FOR MEATS BY SOCIO-ECONOMIC CATEGORIES}

Average one-week beef consumption per capita for the sample of West Virginians increased 7.46 percent during the study period whereas per capita expenditures increased 6.15 percent. Pork consumption per capita, however, was the same in the first sample as the second, despite a 7.87 percent increase in expenditures. For poultry, consumption per capita increased 20 percent and expenditures increased 22.67 percent. Seafood consumption in the 1975 sample was 3.70 percent greater than in the 1973 sample and seafood expenditures increased 29.41 percent.

The socioeconomic characteristics examined in the study included the age, education, and occupation of the principal income earner, household size, and household income. Appendix Tables 1 through 8 show the changes in weekly per capita consumption and expenditures for the four meats in population categories by age of the principal income earner. Appendix Tables 9 through 16 show the same information by education of the principal income earner. Appendix Tables $17-24,25-32$, and 33-40 give consumption and expenditure changes by 
occupation, household size, and income. Appendix Table 41 shows the number of responses and percent of households responding by socioeconomic category for July 1975. This information for the 1973 study can be found in a publication by Kuehn and Bias. ${ }^{\mathbf{1 1}}$

\section{Age of the Principal Income Earner}

Beef. Households in the 35-44, 45-54, and the under 25 years age categories of principal income earner increased their beef consumption to a greater extent than the other age categories. Households whose principal income earner was in the 25-34-year-old group or in the over 65 category decreased per capita consumption and expenditures in July 1975 compared to July 1973.

Pork. The largest increase in pork consumption was by households whose principal income earner was under 25 years old. The largest decrease in pork consumption per capita occurred in the 25-34-year-old category.

Poultry. The only age category of principal income earners with decreased average per capita consumption of poultry was the under 25-year-old group. Households in this category consumed 10.34 percent less poultry in the 1975 study than in the 1973 sample. They also decreased expenditures by 28.41 percent. All of the other age categories had increased consumption per capita during the study period.

Seafood. Only two age categories showed an increase in per capita seafood consumption. The 25-34- and the 55-64-year-old principal income earners' households increased consumption per capita by 33.33 percent. The under 25 category decreased per capita consumption by over 51 percent in the two-year period.

\section{Education of the Principal Income Earner}

Beef. Respondents in only one educational category reported a decrease in per capita consumption and expenditures for beef. The college graduate category of principal income earners decreased one-week per capita consumption by 12.5 percent between 1973 and 1975. These households also spent almost five percent less in 1975 than in 1973. The largest increase in consumption and expenditures during the period was by the $0-7$ years of education category of principal income earners (28.57 percent increase in consumption and 31.78 percent increase in expenditures).

Pork. Three educational categories of principal income earners increased per capita consumption as well as expenditures. These included the 9-11, 13-15, and the college post-graduate (over 16 years) category. Over the study period, the remaining educational groups consumed less pork per capita.

${ }^{11}$ Kuehn and Bias, op. cit., Appendix Table 1. 
Poultry. The college graduate (16 years) and the grade school graduate ( 8 years) reported significant increases in per capita poultry consumption over the two-year period. Principal income earners who were college graduates reported an increase in household consumption per capita of almost 81 percent, and they increased expenditures by 104.26 percent. Households in the grade school graduate category increased consumption by 43.94 percent and expenditures by 61.91 percent. The 0-7 and the 9-11 years categories reported decreases in per capita consumption.

Seafood. Households in the 0-7 years of education category reported the greatest increase in seafood consumption per person. Families in this category consumed 120 percent more per capita in 1975 than in 1973. They also increas. ed expenditures by 60 percent per capita. The 9-11 and the over 16 years categories decreased per capita consumption of seafood between the study years.

\section{Occupation of the Principal Income Earner}

Beef. Of all occupational categories, only four-principal income earners employed as machine operators, craftsmen, retired, and self-employed-reported decreases in per capita consumption of beef and expenditures. The unemployed, sales and clerical, and the white collar categories showed the largest percentage increases in beef consumption. Note, however, that a very small number of respondents were in the unemployed category (10 respondents or 2.38 percent of the sample in 1975).

Pork. Seven occupational categories-housewife, laborer, unemployed, white collar, service worker, craftsmen, and sales and clerical-decreased per capita pork consumption in 1975 compared to the 1973 survey. All of the other categories reported increases over the study period.

Poultry. Only four categories of principal income earners-housewife, unemployed, service worker, and craftsmen-decreased poultry consumption per capita. All of the other categories increased poultry consumption, with farmers, sales and clerical, and white collar workers showing greater increases over the study period.

Seafood. Of all of the occupations of principal income earners, four reported decreasing seafood consumption per capita over the two-year period: farmer, professional, laborer, and service worker categories. All of the remaining occupational groups either maintained the 1973 levels of consumption or increased them by 1975 .

\section{Household Size}

Beef. Households of all family sizes increased their per capita consumption of beef with the exception of single households and families of seven members. These categories reported decreases in per capita consumption in July 1975 
compared to July 1973. The largest number of respondents were in the two-, three-, and four-member family size categories. These respondents reported increases in per capita consumption of beef of $3.21,11.72$, and 14.29 percent, respectively.

Pork. Family sizes of one, two, and six members decreased per capita consumption of pork between the two study years while all other categories increased or maintained the same levels of per capita consumption. Only one ten-member family responded to the questionnaire and this family consumed no pork during the one-week period associated with the 1975 study.

Poultry. All but two family size groups increased per capita consumption of poultry between July 1973 and July 1975. Six- and seven-member families decreased per capita consumption of poultry by 9.43 and 23.94 percent, respectively.

Seafood. Only three family size groups-one-member, four-member, and eight-member-increased average per capita consumption of seafood. All other size categories either decreased or maintained the same levels as in 1973.

\section{Household Income}

Beef. Only one income category reported a decrease in beef consumption. The $\$ 10,000-\$ 14,999$ category decreased one week per capita consumption between July 1973 and July 1975 by 4 percent. The largest increases in beef consumption per capita were exhibited by the $\$ 1,000-\$ 4,999$ and the $\$ 25,000$ and over categories (23.47 and 2.13 percent, respectively).

Pork. The under $\$ 1,000$ and the $\$ 25,000$ and over categories reported increases in average per capita consumption of 27.50 and 58.54 percent. All others decreased per capita pork consumption over the study period.

Poultry. All income categories of households increased poultry consumption over the study period. The largest of these increases were realized by the under $\$ 1,000$, the $\$ 15,000-\$ 24,999$, and the $\$ 1,000-\$ 4,999$ households.

Seafood. All but the two highest household income categories increased per capita seafood consumption. The $\$ 15,000-\$ 24,999$ and the over $\$ 25,000$ households decreased consumption by 9.09 and 36.11 percent, respectively. The largest increase was exhibited by the under $\$ 1,000$ category, but only 12 respondents (2.86 percent of the sample) fell into this category.

\section{EVALUATION OF RESULTS}

\section{Quantities of Meat Purchased}

Table 1 summarizes the changes in one-week per capita consumption (quantity purchased) of the four meats by population categories. Statewide, the sample results showed increases in beef, poultry, and seafood consumption and 
TABLE 1

Changes in Sample One-Week Per Capita Consumption of Meats, July 1973 to July 1975, By Population Categories in West Virginia.

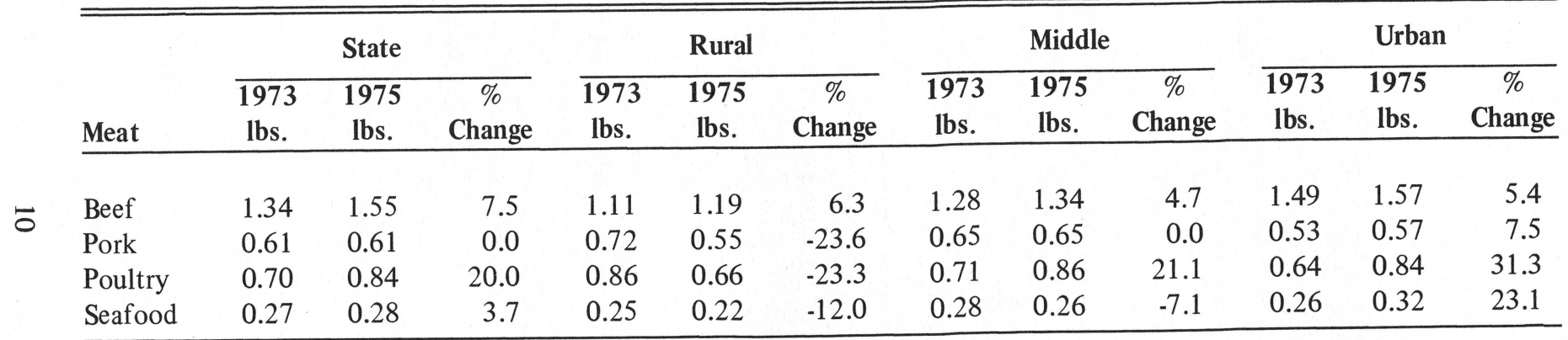


no change in pork consumption. In "rural" areas, however, pork, poultry, and seafood consumption decreased while the quantity of beef purchased increased. The greatest increase was for poultry (31.3 percent), followed by seafood (23.1 percent), pork ( 7.5 percent), and beef (5.4 percent). In the "middle" population areas, beef and poultry consumption increased, pork purchases remained the same, and seafood consumption decreased between July 1973 and July 1975.

Table 2 compares per capita consumption in the sample to estimates of changes in the United States. Consumption of pork, poultry, and seafood declined between 1973 and 1975 in the United States while West Virginians consumed the same amount of pork and increased both poultry and seafood consumption per capita. U.S. consumption of beef increased 12.6 percent while sample consumption only increased 7.5 percent. While "urban" areas of West Virginia increased consumption of each of the meats, "rural" areas of the state more closely followed the nationwide trends of increases in beef consumption and decreases in the purchases of pork, poultry, and seafood.

\section{TABLE 2 \\ Comparison of Sample One-Week Consumption Per Capita and U.S. Average Per Capita Consumption of Meats 1973-1975.}

\begin{tabular}{|c|c|c|c|}
\hline & 1973 & 1975 & $\begin{array}{c}\text { (Percent) } \\
\text { Change }\end{array}$ \\
\hline \multicolumn{4}{|l|}{ Beef } \\
\hline Sample Consumption Per Capita & $1.34 \mathrm{lb}$ & $1.44 \mathrm{lb}$ & 7.5 \\
\hline $\begin{array}{l}\text { U.S. Consumption Per Capita } \\
\text { (third quarter) }\end{array}$ & $19.8 \mathrm{lb}$. & $23.3 \mathrm{lb}$. & 12.6 \\
\hline \multicolumn{4}{|l|}{ Pork } \\
\hline Sample Consumption Per Capita & $0.61 \mathrm{lb}$ & $0.61 \mathrm{lb}$. & 0 \\
\hline $\begin{array}{l}\text { U.S. Consumption Per Capita } \\
\text { (third quarter) }\end{array}$ & $13.0 \mathrm{lb}$. & $11.8 \mathrm{lb}$ & -9.23 \\
\hline \multicolumn{4}{|l|}{ Poultry } \\
\hline Sample Consumption Per Capita & $0.70 \mathrm{lb}$ & 0.84 lb. & 20.0 \\
\hline U.S. Consumption Index (Year) ${ }^{b}$ & 107 & 105 & -1.9 \\
\hline \multicolumn{4}{|l|}{ Seafood } \\
\hline Sample Consumption Per Capita & $0.27 \mathrm{lb}$ & $0.28 \mathrm{lb}$. & 3.7 \\
\hline $\begin{array}{l}\text { U.S. Consumption Index (Year } \\
\text { Preliminary) }\end{array}$ & 117 & 112 & -4.3 \\
\hline
\end{tabular}

${ }^{\mathrm{a}}$ Livestock and Meat Situation, ERS - USDA Bulletin L.M.S. 205 - October 1975.

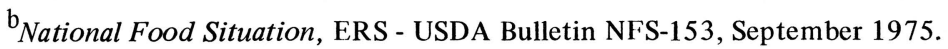




\section{Per Capita Expenditures}

Table 3 summarizes changes in per capita expenditures by population categories for the four meats. Expenditures increased statewide for each of the meats studied. Total expenditures (the sum of per capita expenditures for each meat) increased 11.7 percent for the entire sample. "Middle" and "urban" areas of the state increased total meat expenditures 13.0 and 11.6 percent, respectively, but "rural" respondents decreased total expenditures over the study period.

Table 4 indicates changes in U.S. retail prices for meats. Indexes showed the largest increase was for pork (33.6 percent), followed by seafood (23.9 percent), beef (13.5 percent), and poultry (11.8 percent). The large increase in the price of pork may have been associated with the relatively small increase in pork expenditures. However, U.S. seafood prices also showed a relatively large increase while seafood expenditures by West Virginians increased by a greater percentage. Again, in the case of poultry, U.S. prices increased by 11.8 percent while sample respondents increased expenditures by 22.7 percent.

\section{Expenditures and Income}

Per capita income of sample respondents in the state increased by an average of 25.4 percent between July 1973 and July 1975 (Table 5).

Respondents in "rural" areas of the State reported a 30.4 percent increase, "middle" population areas increased by 16.8 percent and "urban" West Virginians indicated earnings of 26.5 percent more per person as of July, 1975 than in 1973.

The increase nationwide in per capita income was only 17.8 percent between the study years. This increase was exceeded by all but "middle" areas of West Virginia. It should be noted, however, that the U.S. average per capita income was about 55 percent higher than that of West Virginians sampled in this study in 1975.

Data in Table 6 show per capita meat expenditures as a percent of per capita income for 1975 compared to $1973 .{ }^{12}$ For the state as a whole and for each of the population areas, expenditures for meat as a percent of income decreased between 1973 and 1975 .

The greatest decrease was in the proportion of income spent for beef $(-15.4$ percent). The proportion of income spent for pork decreased 13.3 percent, the proportion spent for poultry remained the same $(.025$ percent) and the proportion of income spent on seafood increased slightly over the study period (9.1 percent).

12 It should be noted that the expenditures for one week were taken as a percentage of annual per capita income. This resulted in relatively small percentages. The relationships, however, should not have been affected. 


\section{TABLE 3}

Changes in Sample One-Week Per Capita Expenditures For Meats, July 1973 to July 1975, By Population Categories in West Virginia.

\begin{tabular}{|c|c|c|c|c|c|c|c|c|c|c|c|c|}
\hline \multirow[b]{2}{*}{ Meat } & \multicolumn{3}{|c|}{ State } & \multicolumn{3}{|c|}{ Rural } & \multicolumn{3}{|c|}{ Middle } & \multicolumn{3}{|c|}{ Urban } \\
\hline & 1973 & 1975 & $\begin{array}{c}\% \\
\text { Change }\end{array}$ & 1973 & 1975 & $\begin{array}{c}\% \\
\text { Change }\end{array}$ & 1973 & 1975 & $\begin{array}{c}\% \\
\text { Change }\end{array}$ & 1973 & 1975 & $\begin{array}{c}\% \\
\text { Change } \\
\end{array}$ \\
\hline Beef & $\$ 1.95$ & $\$ 2.07$ & 6.2 & $\$ 1.53$ & $\$ 1.61$ & 5.2 & $\$ 1.80$ & $\$ 1.93$ & 7.2 & $\$ 2.25$ & $\$ 2.27$ & 0.9 \\
\hline Pork & 0.89 & 0.96 & 7.9 & 0.99 & 0.96 & -3.0 & 0.91 & 1.00 & 9.9 & 0.84 & 0.93 & 10.7 \\
\hline Poultry & 0.75 & 0.92 & 22.7 & 0.89 & 0.64 & -28.1 & 0.71 & 0.94 & 32.4 & 0.74 & 0.93 & 25.7 \\
\hline Seafood & 0.34 & 0.44 & 29.4 & 0.34 & 0.29 & -14.7 & 0.35 & 0.39 & 11.4 & 0.32 & 0.50 & 56.3 \\
\hline Total & $\$ 3.93$ & $\$ 4.39$ & 11.7 & $\$ 3.75$ & $\$ 3.50$ & -6.7 & $\$ 3.77$ & $\$ 4.26$ & 13.0 & $\$ 4.15$ & $\$ 4.63$ & 11.6 \\
\hline
\end{tabular}


TABLE 4

U.S. Price Index Number Changes for Meats 1973-75.

\begin{tabular}{lccc}
\hline \hline Meat & July $\mathbf{1 9 7 3}$ & July $\mathbf{1 9 7 5}$ & \% Change \\
\hline Beef & 164.3 & 186.4 & 13.5 \\
Pork & 153.4 & 204.9 & 33.6 \\
Poultry & 154.6 & 172.8 & 11.8 \\
Seafood & 163.8 & 202.9 & 23.9 \\
\hline
\end{tabular}

Source: National Food Situation, USDA Bulletin NFS-146, November 1975, $1969=100$

TABLE 5

Per Capita Income

\begin{tabular}{lrrr}
\hline \hline & 1973 & 1975 & \% Change \\
\hline Rural & $\$ 2,200.24$ & $\$ 2,868.42$ & 30.4 \\
Middle & $2,979.35$ & $3,479.17$ & 16.8 \\
Urban & $3,279.95$ & $4,148.07$ & 26.5 \\
State & $2,982.96$ & $3,740.60$ & 25.4 \\
U.S. $^{a}$ & $4,934.72$ & $5,812.69$ & 17.8 \\
\hline
\end{tabular}

${ }^{\mathrm{a}}$ Derived from total personal income: Survey of Current Business, Bureau of Economic Analysis, U.S. Dept. of Commerce, Vol. 55, No. 8, August 1975 and Vol. 54, No. 6, June 1974 and U.S. population estimates: Current Population Reports, Series P-25, No. 612, November 1975

Table 7 compares real per capita income for the two study years. Real income indicates the amount of goods and services a given absolute income will buy. It is determined by adjusting for changes in the consumer price index. ${ }^{13}$

The amount of goods and services that sample respondents could buy in 1975 was orly 2.5 percent greater than in 1973 . For the U.S., however, real income decreased. Real incomes in "rural" areas of the state increased 6.6 percent and "urban" areas increased 3.4 percent. "Middle" population areas, however, suffered a 4.5 percent decline in the amount of goods and services that could be purchased.

Table 8 shows real per capita meat expenditures as a percent of real income-the proportion of real income that is spent on meats. Percentage changes between 1973 and 1975 indicate differences in spending habits which were not due to price changes.

${ }^{13}$ Real income equals absolute income divided by the consumer price index for that time period and multiplied by 100 . 
TABLE 6

One-Week Sample Per Capita Meat Expenditures as a Percent of Annual Per Capita Income By Population in West Virginia, July 1973 and July 1975.

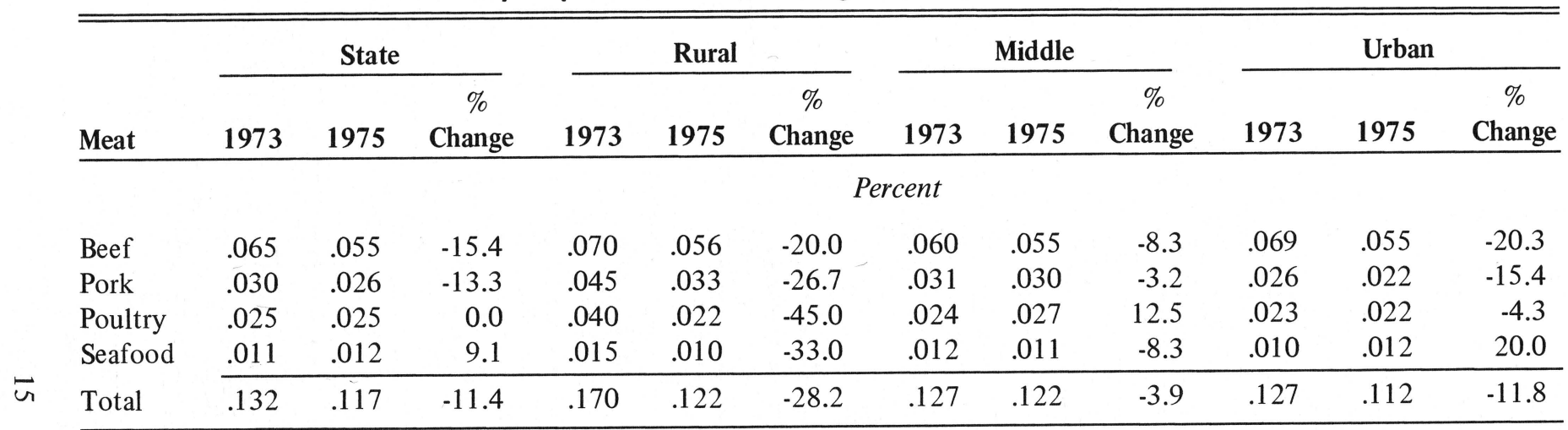

TABLE 7

Real Per Capita Income

\begin{tabular}{lrrr}
\hline \hline & 1973 & 1975 & \% Change \\
\hline Rural & $\$ 1,658.06$ & $\$ 1,767.36$ & 6.6 \\
Middle & $2,245.18$ & $2,143.67$ & -4.5 \\
Urban & $2,471.70$ & $2,555.80$ & 3.4 \\
State & $2,247.90$ & $2,304.74$ & 2.5 \\
U.S. & $3,718.70$ & $3,581.45$ & -3.7 \\
\hline C.P.I.: & July $1973=132.7$ & & \\
& July $1975=162.3$ & &
\end{tabular}


TABLE 8

Changes in One-Week Sample Per Capita Meat Expenditures as a Percent of Annual Real Per Capita Income By Population Categories in West Virginia, July 1973 to July $1975^{a}$.

\begin{tabular}{|c|c|c|c|c|c|c|c|c|c|c|c|c|}
\hline \multirow[b]{2}{*}{ Meat } & \multicolumn{3}{|c|}{ State } & \multicolumn{3}{|c|}{ Rural } & \multicolumn{3}{|c|}{ Middle } & \multicolumn{3}{|c|}{ Urban } \\
\hline & 1973 & 1975 & $\begin{array}{c}\% \\
\text { Change }\end{array}$ & 1973 & 1975 & $\begin{array}{c}\% \\
\text { Change }\end{array}$ & 1973 & 1975 & $\begin{array}{c}\% \\
\text { Change }\end{array}$ & 1973 & 1975 & $\begin{array}{c}\% \\
\text { Change }\end{array}$ \\
\hline Beef & .053 & .048 & -9.4 & .056 & .049 & -12.5 & .049 & .049 & 0.0 & .055 & .039 & -29.1 \\
\hline Pork & .026 & .020 & -23.1 & .039 & .028 & -28.2 & .026 & .023 & -11.5 & .022 & .018 & -18.2 \\
\hline Poultry & .022 & .023 & 4.5 & .035 & .021 & -40.0 & .020 & .025 & 25.0 & .019 & .021 & 10.5 \\
\hline Seafood & .009 & .010 & 11.1 & .013 & .008 & -38.5 & .009 & .009 & 0.0 & .008 & .010 & 25.0 \\
\hline Total & .110 & .101 & -8.2 & .143 & .105 & -26.6 & .105 & .105 & 0.0 & .105 & .096 & -8.6 \\
\hline
\end{tabular}

${ }^{\mathrm{a}}$ Real per capita meat expenditures were determined by deflating the actual expenditures on each meat by its respective retail price index in Table 4. 
The meat expenditures proportion of real income declined for the state. About 8.2 percent less real income was spent on meat in 1975 than in 1973. "Rural" households in the state decreased the meat expenditure proportion of their incomes by almost 27 percent. "Urban" households decreased real meat expenditures by 8.6 percent and residents of "middle" population areas spent about the same for meat in July 1973 as in July 1975.

In "rural" areas of the state, all meat expenditures as a proportion of real income declined. In the "middle" population areas, the beef and seafood proportions remained stable, the pork proportion decreased, and real poultry expenditures as a percent of real income increased. "Urban" areas followed the state behavior of decreasing real beef and pork expenditures and increasing real poultry and seafood expenditures as a proportion of real income.

\section{CONCLUSIONS}

Based on the sample survey of West Virginians, between July 1973 and July 1975:

A. Average one-week per capita consumption of beef, poultry, and seafood increased and pork consumption remained the same for the state as a whole.

1. U.S. per capita consumption declined for pork, poultry, and seafood and increased for beef.

2. "Rural" respondents decreased pork, poultry, seafood, and beef consumption.

B. Average one-week per capita expenditures for all meats increased an average of 11.7 percent in the state.

1. "Rural" household expenditures for meat declined by 6.7 percent; "middle" and "urban" areas increased meat expenditures.

2. U.S. prices of meats increased, ranging from 11.8 percent (poultry) to 33.6 percent (pork).

C. Average one-week per capita income increased 25.4 percent for the state.

1. Per capita income was higher in "urban" and "middle" areas than in "rural" population areas.

2. "Rural" per capita income increased 30.4 percent compared to 16.8 and 26.5 percent in "middle" and "urban" areas.

3. U.S. per capita income increased 17.8 percent during the period.

D. Average one-week per capita meat expenditures declined as a proportion of per capita income by 11.4 percent for the state.

1. "Rural" area households reported a decline of 28.2 percent.

2. The proportion of per capita income spent by households on meats declined 3.9 percent in "middle" areas and 11.8 percent in "urban" areas. 
E. Average real income increased for the state, primarily in "rural" population areas.

1. Average "urban" and "middle" real incomes were much higher absolutely than those of "rural" areas.

2. "Middle" population areas, however, exhibited declines in average real income.

3. U.S. average real income declined.

F. Real meat expenditures as a proportion of real income declined for the state.

1. In terms of beef and pork consumption, consumers were better off. Less of their real incomes was spent on beef and pork while actual consumption of beef and pork increased or remained the same. Also, since less real income was spent on beef and pork, an additional amount of other goods and services could be purchased.

2. However, an additional proportion of real income was spent on poultry and seafood in the latter study period. In this situation consumers spent more of their real incomes for the increased consumption.

3. "Urban" households followed this trend; those in "rural" areas decreased their real expenditures on all meats as a proportion of real income.

\section{BIBLIOGRAPHY}

Kuehn, John P. and James W. Bias, Beef and Pork Consumption in West Virginia, WVU Agr. Exp. Sta. Bulletin 637, March 1975.

Kuehn, John P. and James W. Bias, Poultry, Seafood and Lunch Meat Consumption in West Virginia, WVU Agr. Exp. Sta. Bulletin 638, March 1975.

New York State Division of Housing, A Method for Employing Sampling Techniques in Housing Surveys, September 1948.

U. S. Dept. of Agriculture, Livestock and Meat Situation, Economic Research Service, LMS - 205, October 1975.

U. S. Dept. of Agriculture, National Food Situation, Economic Research Service, NFS - 153, September 1975.

U. S. Dept. of Commerce, Survey of Current Business, Bureau of Economic Analysis, Vol. 54, No. 6, June, 1974 and Vol. 55, No. 8, August 1975. 
Appendix 


\section{APPENDIX TABLE 1}

Changes in One-Week Per Capita Consumption of Beef, July 1973

to July 1975, in West Virginia Population Categories by Age of

Principal Income Earner

\begin{tabular}{|c|c|c|c|c|c|c|c|c|c|c|c|c|}
\hline \multirow[b]{2}{*}{$\begin{array}{l}\text { Age of } \\
\text { Principal } \\
\text { Income Earner }\end{array}$} & \multicolumn{3}{|c|}{ State } & \multicolumn{3}{|c|}{ Rural } & \multicolumn{3}{|c|}{ Middle } & \multicolumn{3}{|c|}{ Urban } \\
\hline & 1973 & 1975 & $\begin{array}{c}\% \\
\text { Change }\end{array}$ & 1973 & 1975 & $\begin{array}{c}\% \\
\text { Change }\end{array}$ & 1973 & 1975 & $\begin{array}{c}\% \\
\text { Change }\end{array}$ & 1973 & 1975 & $\begin{array}{c}\% \\
\text { Change }\end{array}$ \\
\hline Under 25 & 1.35 & 1.54 & 14.07 & 1.94 & 1.83 & -5.67 & 1.33 & 1.22 & -8.27 & 1.14 & 1.66 & 45.61 \\
\hline $25-34$ & 1.28 & 1.27 & -0.78 & 1.00 & 1.07 & 7.00 & 1.32 & 1.16 & -12.12 & 1.31 & 1.45 & 10.69 \\
\hline $35-44$ & 1.14 & 1.31 & 14.91 & 0.80 & 1.02 & 27.50 & 1.16 & 1.36 & 17.24 & 1.25 & 1.33 & 6.40 \\
\hline $45-54$ & 1.48 & 1.69 & 14.19 & 1.23 & 1.88 & 52.85 & 1.44 & 1.63 & 13.19 & 1.59 & 1.74 & 9.43 \\
\hline $55-64$ & 1.33 & 1.45 & 9.02 & 0.27 & 0.73 & 170.37 & 1.28 & 1.24 & -3.13 & 1.61 & 1.68 & 4.35 \\
\hline 65 and over & 1.45 & 1.32 & -8.97 & 1.73 & 0.94 & -45.67 & 1.09 & 1.25 & 14.68 & 1.69 & 1.44 & -14.79 \\
\hline Average & 1.34 & 1.44 & 7.46 & 1.11 & 1.18 & 6.31 & 1.28 & 1.34 & 4.69 & 1.49 & 1.57 & 5.37 \\
\hline
\end{tabular}


APPENDIX TABLE 2

Changes in One-Week Per Capita Expenditures of Beef, July 1973 to July 1975, in West Virginia Population Categories by Age of Principal

Income Earner

\begin{tabular}{|c|c|c|c|c|c|c|c|c|c|c|c|c|}
\hline \multirow[b]{2}{*}{$\begin{array}{l}\text { Age of } \\
\text { Principal } \\
\text { Income Earner }\end{array}$} & \multicolumn{3}{|c|}{ State } & \multicolumn{3}{|c|}{ Rural } & \multicolumn{3}{|c|}{ Middle } & \multicolumn{3}{|c|}{ Urban } \\
\hline & 1973 & 1975 & $\begin{array}{c}\% \\
\text { Change }\end{array}$ & 1973 & 1975 & $\begin{array}{c}\% \\
\text { Change }\end{array}$ & 1973 & 1975 & $\begin{array}{c}\% \\
\text { Change }\end{array}$ & 1973 & 1975 & $\begin{array}{c}\% \\
\text { Change } \\
\end{array}$ \\
\hline Under 25 & 2.46 & 1.97 & -19.92 & 2.50 & 2.83 & 13.20 & 2.13 & 1.61 & -24.41 & 2.79 & 2.04 & -26.88 \\
\hline $25-34$ & 1.89 & 1.79 & -5.29 & 1.81 & 1.37 & -24.31 & 1.89 & 1.48 & -21.69 & 1.89 & 2.27 & 20.11 \\
\hline $35-44$ & 1.58 & 1.93 & 22.15 & 1.10 & 1.55 & 40.91 & 1.54 & 1.82 & 18.18 & 1.82 & 2.08 & 14.29 \\
\hline $45-54$ & 2.20 & 2.46 & 11.82 & 1.36 & 2.55 & 87.50 & 2.13 & 2.35 & 10.33 & 2.46 & 2.56 & 4.07 \\
\hline $55-64$ & 1.91 & 2.16 & 13.09 & 0.60 & 0.91 & 51.67 & 1.68 & 1.98 & 17.86 & 2.45 & 2.41 & -1.63 \\
\hline 65 and over & 1.98 & 1.84 & -7.07 & 2.15 & 1.19 & -44.65 & 1.61 & 1.91 & 18.63 & 2.32 & 1.85 & -20.26 \\
\hline Average & 1.95 & 2.07 & 6.15 & 1.53 & 1.61 & 5.23 & 1.80 & 1.93 & 7.22 & 2.25 & 2.27 & 0.89 \\
\hline
\end{tabular}




\section{APPENDIX TABLE 3}

Changes in One-Week Per Capita Consumption of Pork, July 1973 to July 1975, in West Virginia Population Categories by Age of Principal Income Earner

\begin{tabular}{|c|c|c|c|c|c|c|c|c|c|c|c|c|}
\hline \multirow{2}{*}{$\begin{array}{l}\text { Age of } \\
\text { Principal } \\
\text { Income Earner }\end{array}$} & \multicolumn{3}{|c|}{ State } & \multicolumn{3}{|c|}{ Rural } & \multicolumn{3}{|c|}{ Middle } & \multicolumn{3}{|c|}{ Urban } \\
\hline & 1973 & 1975 & $\begin{array}{c}\% \\
\text { Change }\end{array}$ & 1973 & 1975 & $\begin{array}{c}\% \\
\text { Change }\end{array}$ & 1973 & 1975 & $\begin{array}{c}\% \\
\text { Change } \\
\end{array}$ & 1973 & 1975 & $\begin{array}{c}\% \\
\text { Change } \\
\end{array}$ \\
\hline Under 25 & 0.48 & 0.59 & 22.92 & 0.50 & 0.50 & - & 0.72 & 0.78 & 8.33 & 0.22 & 0.51 & 131.82 \\
\hline $25-34$ & 0.61 & 0.54 & -11.48 & 0.60 & 0.51 & -15.00 & 0.62 & 0.53 & -14.52 & 0.59 & 0.56 & -5.09 \\
\hline $35-44$ & 0.49 & 0.50 & 2.04 & 0.48 & 0.64 & 33.33 & 0.55 & 0.55 & - & 0.42 & 0.43 & 2.38 \\
\hline $45-54$ & 0.61 & 0.60 & -1.64 & 0.61 & 0.44 & -27.87 & 0.65 & 0.68 & 4.62 & 0.56 & 0.53 & -5.36 \\
\hline $55-64$ & 0.68 & 0.69 & 1.47 & 0.60 & 0.63 & 5.00 & 0.79 & 0.69 & -12.66 & 0.59 & 0.69 & 16.95 \\
\hline 65 and Over & 0.68 & 0.67 & -1.47 & 1.15 & 0.63 & -45.22 & 0.58 & 0.76 & 31.03 & 0.51 & 0.59 & 15.69 \\
\hline Average & 0.61 & 0.61 & - & 0.72 & 0.55 & -23.61 & 0.65 & 0.65 & - & 0.53 & 0.57 & 7.55 \\
\hline
\end{tabular}




\section{APPENDIX TABLE 4}

Changes in One-Week Per Capita Expenditures of Pork, July 1973 to July 1975, in West Virginia Population Categories by Age of Principal Income Earner.

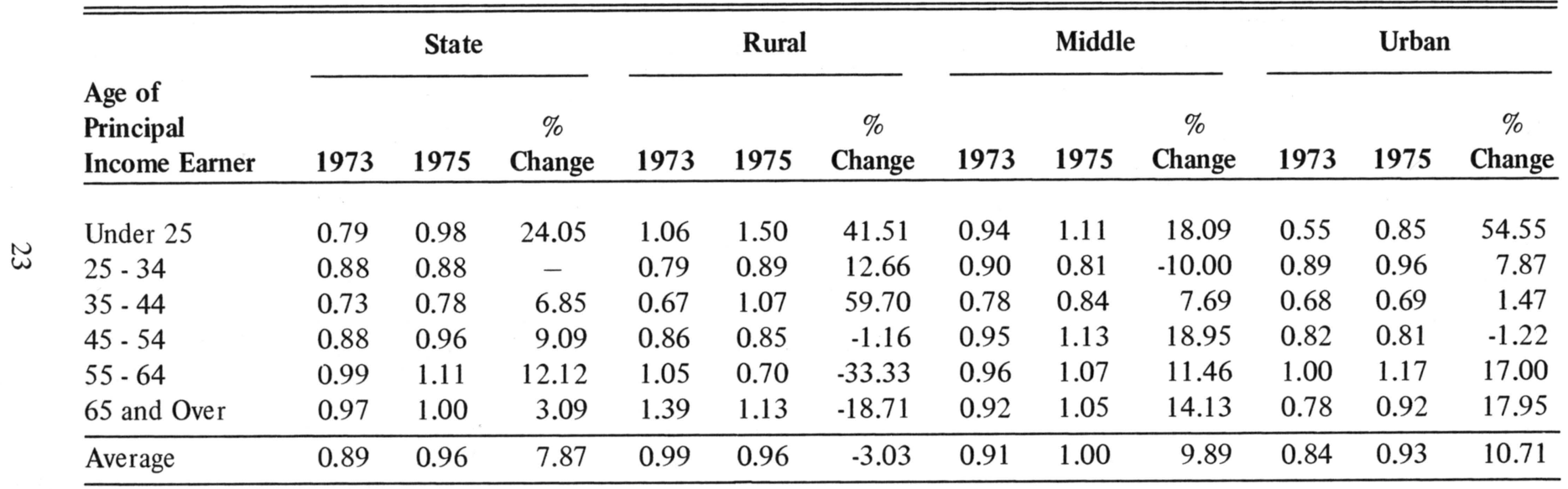


APPENDIX TABLE 5

Changes in One-Week Per Capita Consumption of Poultry, July 1973 to July 1975, in West Virginia Population Categories by Age of Principal Income Earner

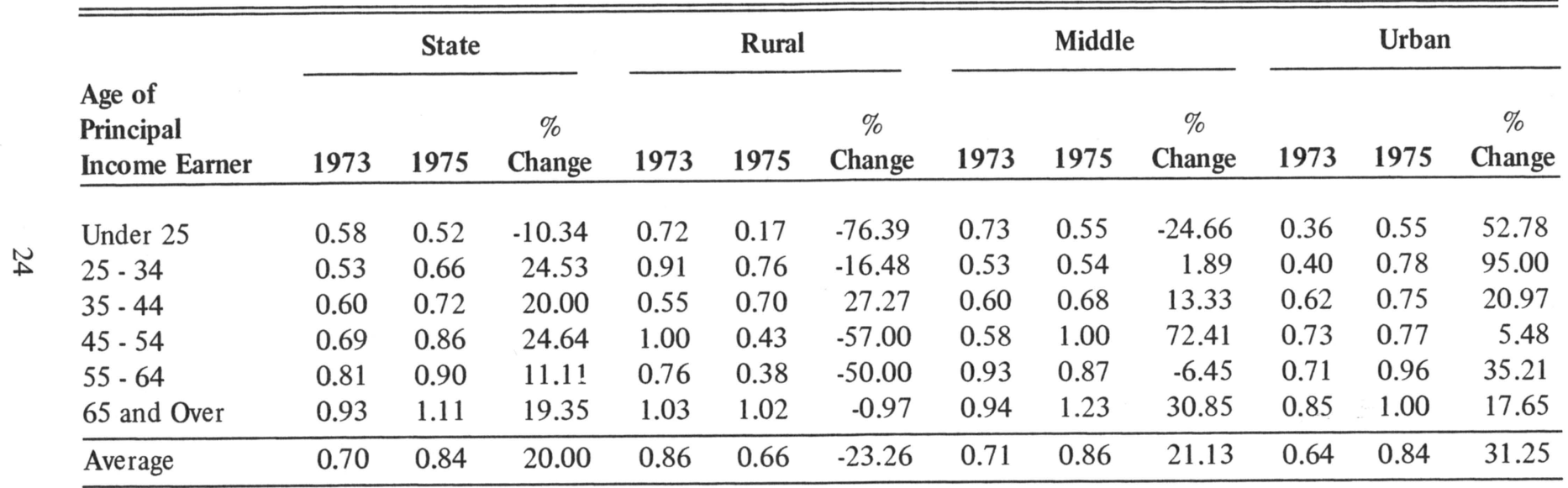




\section{APPENDIX TABLE 6}

Changes in One-Week Per Capita Expenditures of Poultry, July 1973 to July 1975, in West Virginia Population Categories by Age of Principal Income Earner

\begin{tabular}{|c|c|c|c|c|c|c|c|c|c|c|c|c|}
\hline \multirow{2}{*}{$\begin{array}{l}\text { Age of } \\
\text { Principal } \\
\text { Income Earner }\end{array}$} & \multicolumn{3}{|c|}{ State } & \multicolumn{3}{|c|}{ Rural } & \multicolumn{3}{|c|}{ Middle } & \multicolumn{3}{|c|}{ Urban } \\
\hline & 1973 & 1975 & $\begin{array}{c}\% \\
\text { Change } \\
\end{array}$ & 1973 & 1975 & $\begin{array}{c}\% \\
\text { Change }\end{array}$ & 1973 & 1975 & $\begin{array}{c}\% \\
\text { Change }\end{array}$ & 1973 & 1975 & $\begin{array}{c}\% \\
\text { Change }\end{array}$ \\
\hline Under 25 & 0.88 & 0.63 & -28.41 & 1.17 & 0.17 & -85.47 & 0.86 & 0.78 & -9.30 & 0.78 & 0.61 & -21.80 \\
\hline $25-34$ & 0.59 & 0.73 & 23.73 & 0.99 & 0.67 & -32.32 & 0.59 & 0.61 & 3.39 & 0.45 & 0.89 & 97.78 \\
\hline $35-44$ & 0.65 & 0.79 & 21.54 & 0.66 & 0.75 & 13.64 & 0.59 & 0.74 & 25.42 & 0.73 & 0.84 & 15.07 \\
\hline $45-54$ & 0.68 & 0.87 & 27.94 & 0.78 & 0.43 & -44.87 & 0.65 & 1.02 & 56.92 & 0.70 & 0.75 & 7.14 \\
\hline $55-64$ & 0.78 & 0.96 & 23.08 & 0.81 & 0.38 & -53.09 & 0.77 & 1.02 & 32.47 & 0.78 & 0.95 & 21.80 \\
\hline 65 and Over & 1.10 & 1.33 & 20.91 & 1.04 & 1.02 & -1.92 & 1.03 & 1.30 & 26.21 & 1.21 & 1.41 & 16.53 \\
\hline Average & 0.75 & 0.92 & 22.67 & 0.89 & 0.64 & -28.09 & 0.71 & 0.94 & 32.39 & 0.74 & 0.93 & 25.68 \\
\hline
\end{tabular}




\section{APPENDIX TABLE 7}

Changes in One-Week Per Capita Consumption of Seafood, July 1973 to July 1975, in West Virginia Population Categories by Age of Principal Income Earner

\begin{tabular}{|c|c|c|c|c|c|c|c|c|c|c|c|c|}
\hline \multirow[b]{2}{*}{$\begin{array}{l}\text { Age of } \\
\text { Principal } \\
\text { Income Earner }\end{array}$} & \multicolumn{3}{|c|}{ State } & \multicolumn{3}{|c|}{ Rural } & \multicolumn{3}{|c|}{ Middle } & \multicolumn{3}{|c|}{ Urban } \\
\hline & 1973 & 1975 & $\begin{array}{c}\% \\
\text { Change }\end{array}$ & 1973 & 1975 & $\begin{array}{c}\% \\
\text { Change } \\
\end{array}$ & 1973 & 1975 & $\begin{array}{c}\% \\
\text { Change }\end{array}$ & 1973 & 1975 & $\begin{array}{c}\% \\
\text { Change } \\
\end{array}$ \\
\hline Under 25 & 0.39 & 0.19 & -51.28 & 0.31 & 0.17 & -45.16 & 0.60 & 0.11 & -81.67 & 0.21 & 0.22 & 4.76 \\
\hline $25-34$ & 0.21 & 0.28 & 33.33 & 0.14 & 0.36 & 157.14 & 0.25 & 0.24 & -4.00 & 0.20 & 0.31 & 55.00 \\
\hline $35-44$ & 0.26 & 0.24 & -7.69 & 0.20 & 0.41 & 105.00 & 0.28 & 0.17 & -39.29 & 0.25 & 0.26 & 4.00 \\
\hline $45-54$ & 0.33 & 0.32 & -3.03 & 0.29 & 0.10 & -65.52 & 0.32 & 0.33 & 3.13 & 0.35 & 0.33 & -5.71 \\
\hline $55-64$ & 0.24 & 0.32 & 33.33 & 0.11 & - & - & 0.25 & 0.25 & - & 0.27 & 0.40 & 48.15 \\
\hline 65 and Over & 0.26 & 0.25 & -3.85 & 0.43 & 0.06 & -86.05 & 0.21 & 0.28 & 33.33 & 0.20 & 0.23 & 15.00 \\
\hline Average & 0.27 & 0.28 & 3.70 & 0.25 & 0.66 & 164.00 & 0.28 & 0.26 & -7.14 & 0.26 & 0.32 & 23.08 \\
\hline
\end{tabular}




\section{APPENDIX TABLE 8}

Changes in One-Week Per Capita Expenditures of Seafood, July 1973 to July 1975, in West Virginia Population Categories by Age of Principal Income Earner

\begin{tabular}{|c|c|c|c|c|c|c|c|c|c|c|c|c|}
\hline \multirow{2}{*}{$\begin{array}{l}\text { Age of } \\
\text { Principal } \\
\text { Income Earner }\end{array}$} & \multicolumn{3}{|c|}{ State } & \multicolumn{3}{|c|}{ Rural } & \multicolumn{3}{|c|}{ Middle } & \multicolumn{3}{|c|}{ Urban } \\
\hline & 1973 & 1975 & $\begin{array}{c}\% \\
\text { Change }\end{array}$ & 1973 & 1975 & $\begin{array}{c}\% \\
\text { Change }\end{array}$ & 1973 & 1975 & $\begin{array}{c}\% \\
\text { Change }\end{array}$ & 1973 & 1975 & $\begin{array}{c}\% \\
\text { Change }\end{array}$ \\
\hline Under 25 & 0.57 & 0.35 & -38.60 & 0.58 & 0.17 & -70.69 & 0.76 & 0.28 & -63.16 & 0.38 & 0.41 & 7.90 \\
\hline $25-34$ & 0.30 & 0.42 & 40.00 & 0.21 & 0.51 & 142.86 & 0.38 & 0.32 & -15.79 & 0.23 & 0.51 & 121.74 \\
\hline $35-44$ & 0.30 & 0.39 & 30.00 & 0.30 & 0.48 & 60.00 & 0.28 & 0.25 & -10.71 & 0.31 & 0.49 & 58.07 \\
\hline $45-54$ & 0.42 & 0.48 & 14.29 & 0.43 & 0.10 & -76.74 & 0.41 & 0.52 & 26.83 & 0.43 & 0.48 & 11.63 \\
\hline $55-64$ & 0.31 & 0.46 & 48.39 & 0.17 & - & - & 0.30 & 0.38 & 26.67 & 0.35 & 0.57 & 62.86 \\
\hline 65 and Over & 0.30 & 0.41 & 36.67 & 0.50 & 0.06 & -88.00 & 0.28 & 0.42 & 50.00 & 0.20 & 0.44 & 120.00 \\
\hline Average & 0.34 & 0.44 & 29.41 & 0.34 & 0.64 & 88.24 & 0.35 & 0.39 & 11.43 & 0.32 & 0.50 & 56.25 \\
\hline
\end{tabular}


APPENDIX TABLE 9

Changes in One-Week Per Capita Consumption of Beef, July 1973 to July 1975, in West Virginia Population Categories by Education of Principal Income Earner

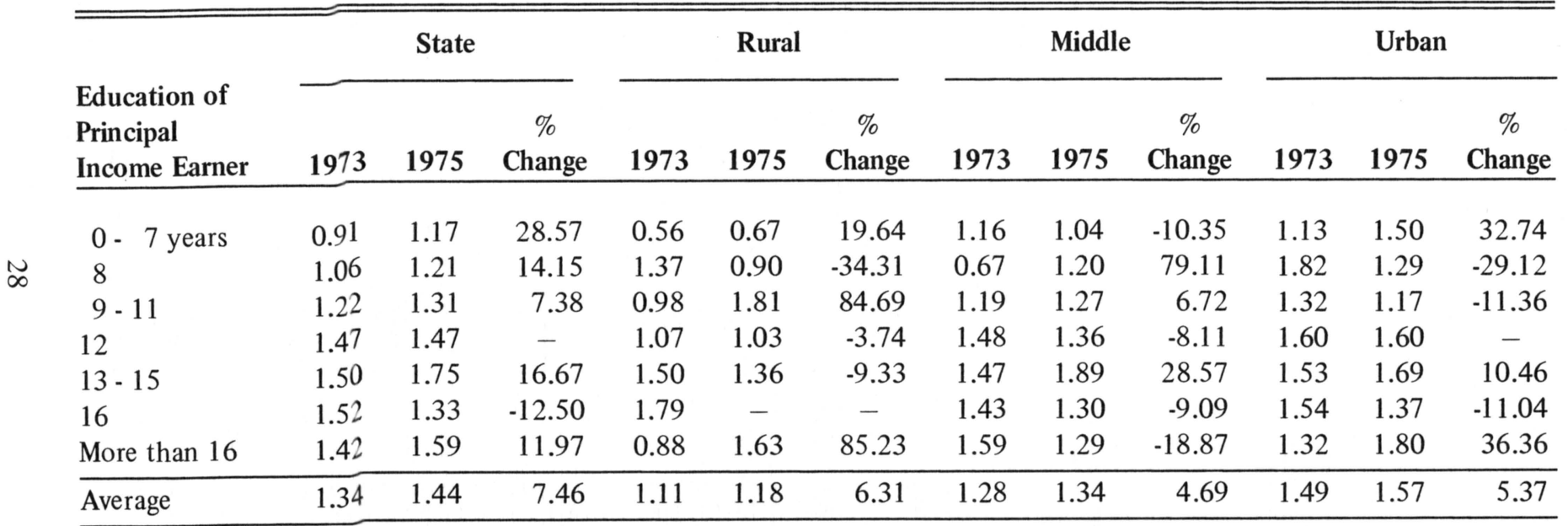




\section{APPENDIX TABLE 10}

Changes in One-Week Per Capita Expenditures of Beef, July 1973 to July 1975, in West Virginia Population Categories by Education of Principal Income Earner

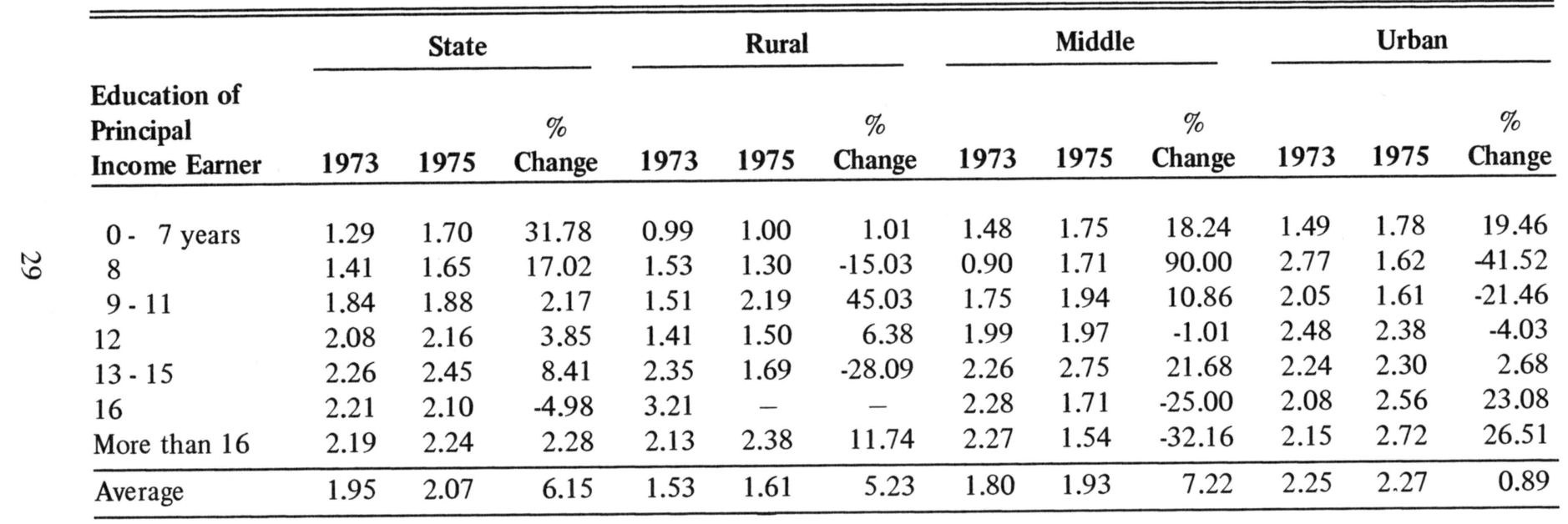


APPENDIX TABLE 11

Changes in One-Week Per Capita Consumption of Pork, July 1973 to July 1975, in West Virginia Population Categories by Education of Principal Income Earner

\begin{tabular}{|c|c|c|c|c|c|c|c|c|c|c|c|c|}
\hline \multirow[b]{2}{*}{$\begin{array}{l}\text { Education of } \\
\text { Principal } \\
\text { Income Earner }\end{array}$} & \multicolumn{3}{|c|}{ State } & \multicolumn{3}{|c|}{ Rural } & \multicolumn{3}{|c|}{ Middle } & \multicolumn{3}{|c|}{ Urban } \\
\hline & 1973 & 1975 & $\begin{array}{c}\% \\
\text { Change } \\
\end{array}$ & 1973 & 1975 & $\begin{array}{c}\% \\
\text { Change }\end{array}$ & 1973 & 1975 & $\begin{array}{c}\% \\
\text { Change }\end{array}$ & 1973 & 1975 & $\begin{array}{c}\% \\
\text { Change }\end{array}$ \\
\hline $0-7$ years & 0.79 & 0.67 & -15.19 & 0.77 & 0.42 & -45.45 & 0.73 & 0.72 & -1.37 & 0.85 & 0.66 & -22.35 \\
\hline 8 & 0.68 & 0.59 & -13.24 & 0.98 & 0.86 & -12.25 & 0.65 & 0.59 & -9.23 & 0.43 & 0.55 & 27.91 \\
\hline $9-11$ & 0.55 & 0.73 & 32.73 & 0.27 & 0.42 & 55.56 & 0.60 & 0.89 & 48.33 & 0.56 & 0.50 & -10.71 \\
\hline 12 & 0.63 & 0.56 & -11.11 & 0.72 & 0.51 & -29.17 & 0.68 & 0.57 & -16.18 & 0.53 & 0.57 & 7.55 \\
\hline $13-15$ & 0.57 & 0.61 & 7.02 & 0.38 & 0.75 & 97.37 & 0.63 & 0.67 & 6.35 & 0.57 & 0.57 & - \\
\hline 16 & 0.56 & 0.53 & -5.36 & 0.38 & - & - & 0.29 & 0.49 & 68.97 & 0.74 & 0.58 & -21.62 \\
\hline More than 16 & 0.51 & 0.58 & 13.73 & 0.63 & 0.63 & - & 0.80 & 0.62 & -22.50 & 0.33 & 0.56 & 69.70 \\
\hline Average & 0.61 & 0.61 & - & 0.72 & 0.55 & -23.61 & 0.65 & 0.65 & - & 0.53 & 0.57 & 7.55 \\
\hline
\end{tabular}




\section{APPENDIX TABLE 12}

Changes in One-Week Per Capita Expenditures of Pork, July 1973 to July 1975, in West Virginia Population Categories by Education of Principal Income Earner

\begin{tabular}{|c|c|c|c|c|c|c|c|c|c|c|c|c|}
\hline \multirow{2}{*}{$\begin{array}{l}\text { Education of } \\
\text { Principal } \\
\text { Income Earner }\end{array}$} & \multicolumn{3}{|c|}{ State } & \multicolumn{3}{|c|}{ Rural } & \multicolumn{3}{|c|}{ Middle } & \multicolumn{3}{|c|}{ Urban } \\
\hline & 1973 & 1975 & $\begin{array}{c}\% \\
\text { Change }\end{array}$ & 1973 & 1975 & $\begin{array}{c}\% \\
\text { Change }\end{array}$ & 1973 & 1975 & $\begin{array}{c}\% \\
\text { Change }\end{array}$ & 1973 & 1975 & $\begin{array}{c}\% \\
\text { Change }\end{array}$ \\
\hline $0-7$ years & 1.18 & 0.96 & -18.64 & 1.34 & 0.92 & -31.34 & 0.97 & 1.01 & 4.12 & 1.17 & 0.89 & -23.93 \\
\hline 8 & 0.96 & 0.92 & -4.17 & 1.27 & 1.15 & -9.45 & 0.88 & 0.90 & 2.27 & 0.83 & 0.93 & 12.05 \\
\hline $9-11$ & 0.83 & 1.24 & 49.40 & 0.33 & 0.80 & 142.42 & 0.80 & 1.56 & 95.00 & 1.00 & 0.72 & -28.00 \\
\hline 12 & 0.87 & 0.94 & 8.05 & 0.90 & 0.89 & -1.11 & 0.88 & 0.94 & 6.82 & 0.82 & 0.94 & 14.63 \\
\hline $13-15$ & 0.88 & 1.02 & 15.91 & 0.53 & 1.25 & 135.85 & 0.95 & 1.06 & 11.58 & 0.90 & 0.97 & 7.78 \\
\hline 16 & 0.84 & 0.87 & 3.57 & 0.54 & - & - & 0.59 & 0.72 & 22.03 & 1.01 & 1.04 & 2.97 \\
\hline More than 16 & 0.83 & 0.80 & -3.61 & 1.13 & 1.13 & - & 1.24 & 0.70 & -43.55 & 0.57 & 0.86 & 50.88 \\
\hline Average & 0.89 & 0.96 & 7.87 & 0.99 & 0.96 & -3.03 & 0.91 & 1.00 & 9.89 & 0.84 & 0.93 & 10.71 \\
\hline
\end{tabular}




\section{APPENDIX TABLE 13}

Changes in One-Week Per Capita Consumption of Poultry, July 1973 to July 1975, in West Virginia Population Categories by Education of Principal Income Earner

\begin{tabular}{|c|c|c|c|c|c|c|c|c|c|c|c|c|}
\hline \multirow{2}{*}{$\begin{array}{l}\text { Education of } \\
\text { Principal } \\
\text { Income Earner }\end{array}$} & \multicolumn{3}{|c|}{ State } & \multicolumn{3}{|c|}{ Rural } & \multicolumn{3}{|c|}{ Middle } & \multicolumn{3}{|c|}{ Urban } \\
\hline & 1973 & 1975 & $\begin{array}{c}\% \\
\text { Change }\end{array}$ & 1973 & 1975 & $\begin{array}{c}\% \\
\text { Change }\end{array}$ & 1973 & 1975 & $\begin{array}{c}\% \\
\text { Change }\end{array}$ & 1973 & 1975 & $\begin{array}{c}\% \\
\text { Change } \\
\end{array}$ \\
\hline $0-7$ years & 0.77 & 0.76 & -1.30 & 0.74 & 0.78 & 5.41 & 0.91 & 0.75 & -17.58 & 0.68 & 0.78 & 14.71 \\
\hline 8 & 0.66 & 0.95 & 43.94 & 0.97 & 0.84 & -13.40 & 0.56 & 0.95 & 69.64 & 0.59 & 0.96 & 62.71 \\
\hline $9 \cdot 11$ & 0.89 & 0.86 & -3.37 & 1.23 & 0.23 & -18.30 & 0.86 & 1.04 & 20.93 & 0.85 & 0.72 & -15.29 \\
\hline 12 & 0.69 & 0.79 & 14.49 & 0.71 & 0.66 & -7.04 & 0.68 & 0.83 & 22.06 & 0.69 & 0.77 & 11.59 \\
\hline $13-15$ & 0.68 & 0.87 & 27.94 & 1.05 & 1.03 & -1.90 & 0.72 & 0.74 & 2.78 & 0.58 & 0.95 & 63.79 \\
\hline 16 & 0.42 & 0.76 & 80.95 & 0.88 & - & - & 0.33 & 0.64 & 103.03 & 0.43 & 0.86 & 100.00 \\
\hline More than 16 & 0.78 & 0.96 & 23.08 & 0.38 & 0.63 & 65.79 & 1.00 & 1.05 & 5.00 & 0.66 & 0.91 & 37.88 \\
\hline Average & 0.70 & 0.84 & 20.00 & 0.86 & 0.66 & -23.26 & 0.71 & 0.86 & 21.13 & 0.64 & 0.84 & 31.25 \\
\hline
\end{tabular}


APPENDIX TABLE 14

Changes in One-Week Per Capita Expenditures of Poultry, July 1973 to July 1975, in West Virginia Population Categories by Education of Principal Income Earner

\begin{tabular}{|c|c|c|c|c|c|c|c|c|c|c|c|c|}
\hline \multirow{2}{*}{$\begin{array}{l}\text { Education of } \\
\text { Principal } \\
\text { Income Earner }\end{array}$} & \multicolumn{3}{|c|}{ State } & \multicolumn{3}{|c|}{ Rural } & \multicolumn{3}{|c|}{ Middle } & \multicolumn{3}{|c|}{ Urban } \\
\hline & 1973 & 1975 & $\begin{array}{c}\% \\
\text { Change }\end{array}$ & 1973 & 1975 & $\begin{array}{c}\% \\
\text { Change }\end{array}$ & 1973 & 1975 & $\begin{array}{c}\% \\
\text { Change }\end{array}$ & 1973 & 1975 & $\begin{array}{c}\% \\
\text { Change }\end{array}$ \\
\hline $0-7$ years & 0.85 & 0.79 & -7.06 & 0.84 & 0.94 & 11.91 & 0.91 & 0.80 & -12.09 & 0.81 & 0.72 & -11.11 \\
\hline 8 & 0.63 & 1.02 & 61.91 & 0.92 & 0.73 & -20.65 & 0.51 & 1.04 & 103.92 & 0.66 & 1.03 & 56.06 \\
\hline 12 & 0.79 & 0.86 & 8.86 & 0.73 & 0.59 & -19.18 & 0.67 & 0.98 & 46.27 & 1.00 & 0.80 & -20.00 \\
\hline $13-15$ & 0.77 & 0.87 & 12.99 & 1.33 & 0.97 & -27.07 & 0.89 & 0.81 & -8.99 & 0.58 & 0.91 & 56.90 \\
\hline 16 & 0.47 & 0.96 & 104.26 & 1.04 & - & - & 0.44 & 0.75 & 70.46 & 0.43 & 1.20 & 179.07 \\
\hline More than 16 & 0.78 & 1.17 & 50.00 & 0.88 & 0.63 & -28.41 & 0.97 & 0.98 & 1.03 & 0.67 & 1.33 & 98.51 \\
\hline Average & 0.75 & 0.92 & 22.67 & 0.89 & 0.64 & -28.09 & 0.71 & 0.94 & 32.39 & 0.74 & 0.93 & 25.68 \\
\hline
\end{tabular}


APPENDIX TABLE 15

Changes in One-Week Per Capita Consumption of Seafood, July 1973 to July 1975, in West Virginia Population Categories by Education of Principal Income Earner

\begin{tabular}{|c|c|c|c|c|c|c|c|c|c|c|c|c|}
\hline \multirow{2}{*}{$\begin{array}{l}\text { Education of } \\
\text { Principal } \\
\text { Income Earner }\end{array}$} & \multicolumn{3}{|c|}{ State } & \multicolumn{3}{|c|}{ Rural } & \multicolumn{3}{|c|}{ Middle } & \multicolumn{3}{|c|}{ Urban } \\
\hline & 1973 & 1975 & $\begin{array}{c}\% \\
\text { Change }\end{array}$ & 1973 & 1975 & $\begin{array}{c}\% \\
\text { Change }\end{array}$ & 1973 & 1975 & $\begin{array}{c}\% \\
\text { Change }\end{array}$ & 1973 & 1975 & $\begin{array}{c}\% \\
\text { Change } \\
\end{array}$ \\
\hline $0-7$ years & 0.10 & 0.22 & 120.00 & 0.13 & - & - & 0.11 & 0.17 & 54.55 & 0.04 & 0.36 & 800.00 \\
\hline 8 & 0.22 & 0.25 & 13.64 & 0.38 & 0.51 & 34.21 & 0.18 & 0.22 & 22.22 & 0.13 & 0.25 & 92.31 \\
\hline $9-11$ & 0.24 & 0.23 & -4.17 & 0.34 & 0.18 & -47.06 & 0.24 & 0.25 & 4.17 & 0.20 & 0.21 & 5.00 \\
\hline 12 & 0.27 & 0.29 & 7.40 & 0.19 & 0.27 & 42.11 & 0.28 & 0.27 & -3.57 & 0.29 & 0.31 & 6.90 \\
\hline $13-15$ & 0.33 & 0.35 & 6.06 & 0.17 & 0.14 & -17.65 & 0.35 & 0.36 & 2.86 & 0.34 & 0.36 & 5.88 \\
\hline 16 & 0.25 & 0.32 & 28.00 & 0.46 & - & - & 0.19 & 0.22 & 15.79 & 0.26 & 0.42 & 61.54 \\
\hline More than 16 & 0.37 & 0.28 & -24.32 & 0.38 & - & - & 0.50 & 0.30 & -40.00 & 0.29 & 0.28 & -3.45 \\
\hline Average & 0.27 & 0.28 & 3.70 & 0.25 & 0.22 & -12.00 & 0.28 & 0.26 & -7.14 & 0.26 & 0.32 & 23.08 \\
\hline
\end{tabular}




\section{APPENDIX TABLE 16}

Changes in One-Week Per Capita Expenditures of Seafood, July 1973 to July 1975, in West Virginia Population Categories by Education of Principal Income Earner

\begin{tabular}{|c|c|c|c|c|c|c|c|c|c|c|c|c|}
\hline \multirow{2}{*}{$\begin{array}{l}\text { Education of } \\
\text { Principal } \\
\text { Income Earner }\end{array}$} & \multicolumn{3}{|c|}{ State } & \multicolumn{3}{|c|}{ Rural } & \multicolumn{3}{|c|}{ Middle } & \multicolumn{3}{|c|}{ Urban } \\
\hline & 1973 & 1975 & $\begin{array}{c}\% \\
\text { Change }\end{array}$ & 1973 & 1975 & $\begin{array}{c}\% \\
\text { Change }\end{array}$ & 1973 & 1975 & $\begin{array}{c}\% \\
\text { Change }\end{array}$ & 1973 & 1975 & $\begin{array}{c}\% \\
\text { Change }\end{array}$ \\
\hline $0-7$ years & 0.15 & 0.24 & 60.00 & 0.24 & - & - & 0.11 & 0.24 & 118.18 & 0.07 & 0.30 & 328.57 \\
\hline 8 & 0.25 & 0.32 & 28.00 & 0.39 & 0.51 & 30.77 & 0.23 & 0.28 & 21.74 & 0.16 & 0.35 & 118.75 \\
\hline $9-11$ & 0.31 & 0.39 & 25.81 & 0.34 & 0.18 & -47.06 & 0.28 & 0.46 & 64.29 & 0.32 & 0.33 & 3.13 \\
\hline 12 & 0.33 & 0.46 & 39.39 & 0.33 & 0.39 & 18.18 & 0.35 & 0.45 & 28.57 & 0.32 & 0.49 & 53.13 \\
\hline $13-15$ & 0.43 & 0.54 & 25.58 & 0.22 & 0.25 & 13.64 & 0.46 & 0.51 & 10.87 & 0.44 & 0.58 & 31.82 \\
\hline 16 & 0.32 & 0.57 & 78.13 & 0.71 & - & - & 0.25 & 0.36 & 44.00 & 0.34 & 0.81 & 138.24 \\
\hline More than 16 & 0.47 & 0.44 & -6.38 & 1.13 & - & - & 0.67 & 0.33 & -50.75 & 0.33 & 0.54 & 63.64 \\
\hline Average & 0.34 & 0.44 & 29.41 & 0.34 & 0.29 & -14.71 & 0.35 & 0.39 & 11.43 & 0.32 & 0.50 & 56.25 \\
\hline
\end{tabular}


APPENDIX TABLE 17

Changes in One-Week Per Capita Consumption of Beef, July 1973 to July 1975, in West Virginia Population Categories by Occupation of Principal Income Earner

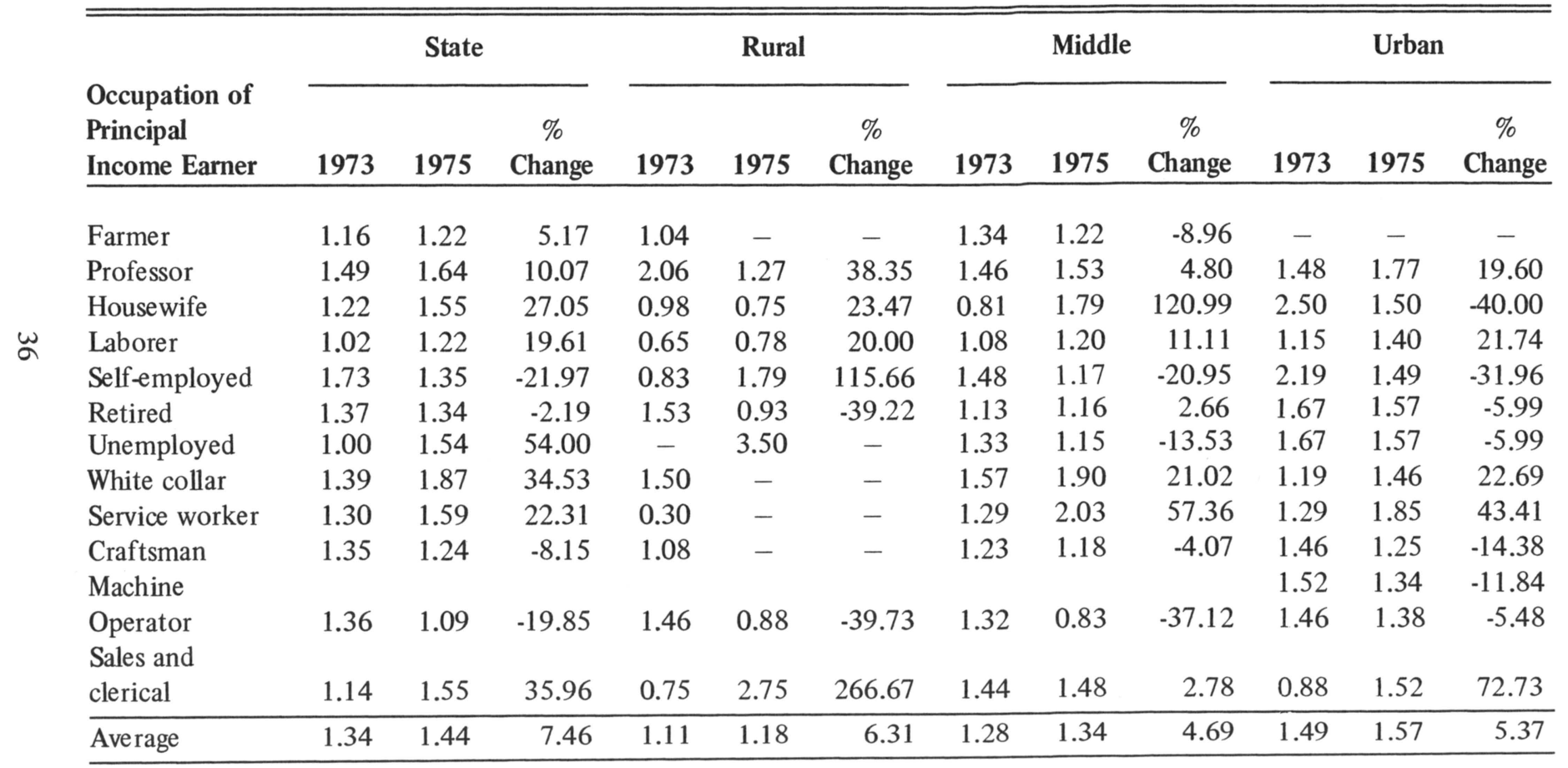


APPENDIX TABLE 18

Changes in One-Week Per Capita Expenditures of Beef, July 1973 to July 1975,

in West Virginia Population Categories by Occupation of Principal Income Earner

\begin{tabular}{|c|c|c|c|c|c|c|c|c|c|c|c|c|}
\hline \multirow{2}{*}{$\begin{array}{l}\text { Occupation of } \\
\text { Principal } \\
\text { Income Earner }\end{array}$} & \multicolumn{3}{|c|}{ State } & \multicolumn{3}{|c|}{ Rural } & \multicolumn{3}{|c|}{ Middle } & \multicolumn{3}{|c|}{ Urban } \\
\hline & 1973 & 1975 & $\begin{array}{c}\% \\
\text { Change }\end{array}$ & 1973 & 1975 & $\begin{array}{c}\% \\
\text { Change }\end{array}$ & 1973 & 1975 & $\begin{array}{c}\% \\
\text { Change }\end{array}$ & 1973 & 1975 & $\begin{array}{c}\% \\
\text { Change }\end{array}$ \\
\hline Farmer & 0.97 & 2.05 & 111.34 & 1.25 & - & - & 0.55 & 2.05 & 272.73 & - & - & - \\
\hline Professor & 2.18 & 2.41 & 10.55 & 3.17 & 1.96 & -38.17 & 2.10 & 2.06 & -1.91 & 2.16 & 2.73 & 26.39 \\
\hline Housewife & 1.48 & 2.28 & 54.05 & 1.25 & 1.75 & 40.00 & 0.94 & 3.25 & 245.75 & 3.00 & 1.67 & -44.33 \\
\hline Laborer & 1.45 & 1.69 & 16.55 & 0.76 & 1.10 & 44.74 & 1.61 & 1.67 & 3.73 & 1.52 & 1.93 & 26.97 \\
\hline Self-employed & 2.50 & 2.10 & -16.00 & 1.13 & 2.20 & 94.69 & 2.05 & 1.81 & -11.71 & 3.25 & 2.47 & -24.00 \\
\hline Retired & 1.90 & 1.84 & -3.16 & 2.24 & 0.98 & -56.25 & 1.54 & 1.67 & 8.44 & 2.32 & 2.11 & -9.05 \\
\hline Unemployed & 1.96 & 2.22 & 13.27 & - & 4.50 & - & 3.03 & 2.08 & -31.35 & 1.56 & 1.88 & 20.51 \\
\hline White collar & 2.07 & 2.81 & 35.75 & 2.67 & - & - & 2.01 & 2.57 & 27.86 & 2.07 & 2.97 & 43.48 \\
\hline Service worker & 1.66 & 2.31 & 39.16 & 0.50 & - & - & 1.55 & 2.93 & 89.03 & 1.99 & 1.81 & -9.05 \\
\hline Craftsman & 2.88 & 1.80 & -37.50 & 0.76 & - & - & 1.82 & 1.63 & -10.44 & 3.10 & 2.09 & -32.58 \\
\hline Machine & & & & & & & & & & & & \\
\hline Operator & 2.19 & 1.37 & -37.44 & 2.52 & 1.13 & -55.16 & 2.08 & 1.25 & -39.90 & 2.32 & 1.55 & -33.19 \\
\hline $\begin{array}{l}\text { Sales and } \\
\text { clerical }\end{array}$ & 1.98 & 2.33 & 17.68 & 0.25 & 4.25 & $1,600.00$ & 2.35 & 2.30 & -2.13 & 1.77 & 2.25 & 27.12 \\
\hline Average & 1.95 & 2.07 & 6.15 & 1.53 & 1.61 & 5.23 & 1.80 & 1.93 & 7.22 & 2.25 & 2.27 & 0.89 \\
\hline
\end{tabular}


APPENDIX TABLE 19

Changes in One-Week Per Capita Consumption of Pork, July 1973 to July 1975, in West Virginia Population Categories by Occupation of Principal Income Earner

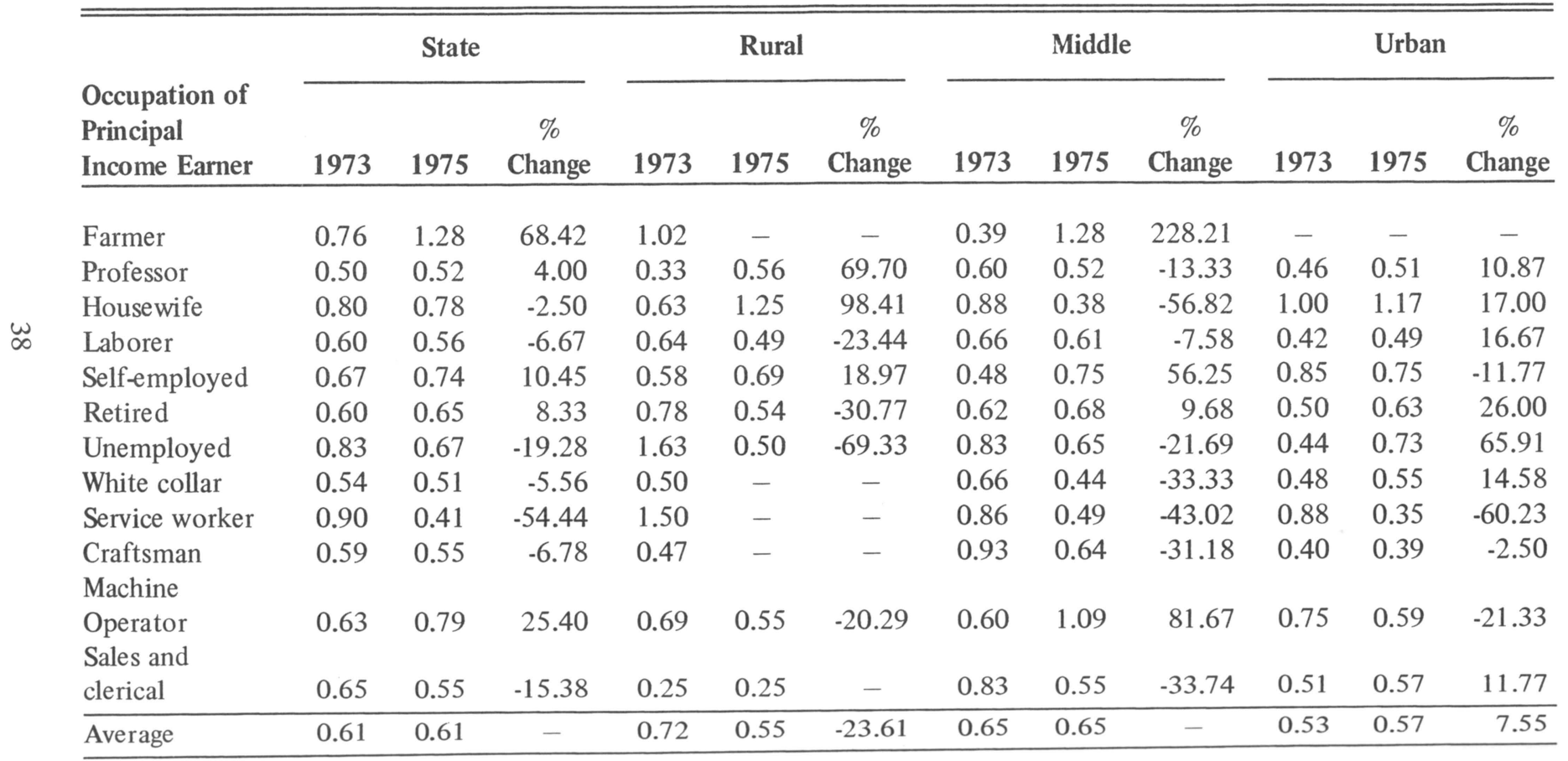


APPENDIX TABLE 20

Changes in One-Week Per Capita Expenditures of Pork, July 1973 to July 1975, in West Virginia Population Categories by Occupation of Principal Income Earner

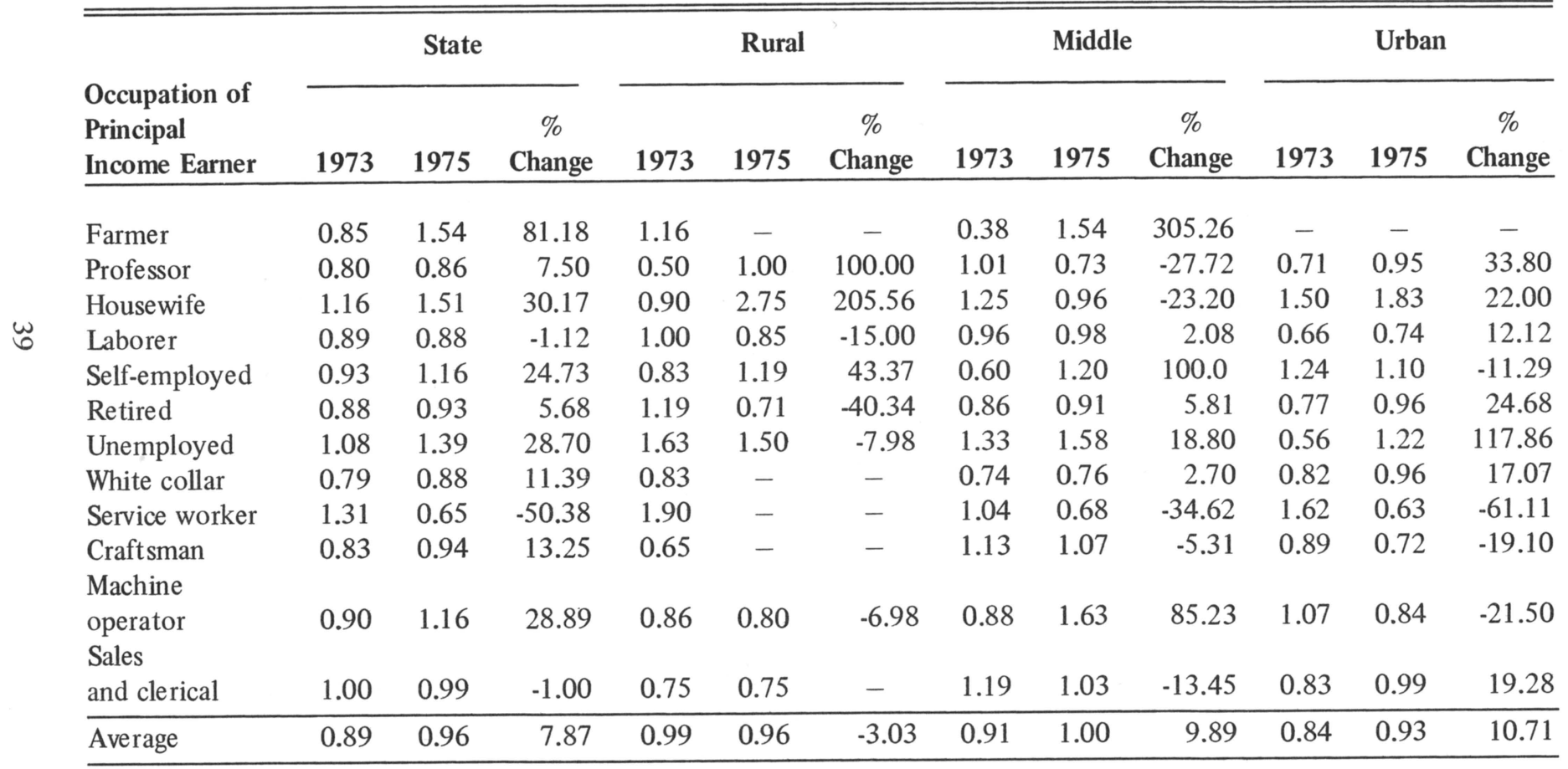




\section{APPENDIX TABLE 21}

Changes in One-Week Per Capita Consumption of Poultry, July 1973 to July 1975, in West Virginia Population Categories by Occupation of Principal Income Earner

\begin{tabular}{|c|c|c|c|c|c|c|c|c|c|c|c|c|}
\hline \multirow{2}{*}{$\begin{array}{l}\text { Occupation of } \\
\text { Principal } \\
\text { Income Earner }\end{array}$} & \multicolumn{3}{|c|}{ State } & \multicolumn{3}{|c|}{ Rural } & \multicolumn{3}{|c|}{ Middle } & \multicolumn{3}{|c|}{ Urban } \\
\hline & 1973 & 1975 & $\begin{array}{c}\% \\
\text { Change }\end{array}$ & 1973 & 1975 & $\begin{array}{c}\% \\
\text { Change }\end{array}$ & 1973 & 1975 & $\begin{array}{c}\% \\
\text { Change }\end{array}$ & 1973 & 1975 & $\begin{array}{c}\% \\
\text { Change }\end{array}$ \\
\hline Farmer & 0.54 & 1.38 & 155.56 & 0.49 & - & - & 0.62 & 1.38 & 122.58 & - & - & - \\
\hline Professor & 0.66 & 0.77 & 16.67 & 0.67 & 0.77 & 14.93 & 0.69 & 0.83 & 20.29 & 0.65 & 0.73 & 12.31 \\
\hline Housewife & 1.20 & 0.49 & -59.17 & 1.00 & 0.25 & -75.00 & 1.25 & 0.79 & -36.80 & 1.50 & 0.17 & -88.67 \\
\hline Laborer & 0.58 & 0.74 & 27.59 & 0.76 & 0.47 & -38.16 & 0.53 & 0.74 & 39.62 & 0.59 & 0.81 & 37.29 \\
\hline Self-employed & 0.70 & 0.86 & 22.86 & 1.00 & 0.81 & -19.00 & 0.61 & 0.82 & 34.42 & 0.70 & 0.92 & 31.43 \\
\hline Retired & 0.88 & 1.05 & 19.32 & 1.09 & 1.03 & -5.51 & 0.95 & 0.98 & 3.16 & 0.69 & 1.12 & 62.32 \\
\hline Unemployed & 0.90 & 0.86 & -4.44 & 0.88 & - & - & 1.00 & 0.70 & -30.00 & 0.81 & 1.16 & 43.21 \\
\hline White collar & 0.54 & 0.78 & 44.44 & 0.50 & - & - & 0.74 & 0.82 & 10.81 & 0.43 & 0.75 & 74.42 \\
\hline Service worker & 0.69 & 0.63 & -8.70 & 0.70 & - & - & 0.71 & 0.58 & -18.31 & 0.67 & 0.67 & - \\
\hline Craftsman & 0.77 & 0.69 & -10.39 & 0.60 & - & - & 0.82 & 0.76 & -7.32 & 0.80 & 0.56 & -30.00 \\
\hline Operator & 0.75 & 0.78 & 4.00 & 1.39 & 0.56 & -59.71 & 0.58 & 0.87 & 50.00 & 0.78 & 0.76 & -2.56 \\
\hline $\begin{array}{l}\text { Sales and } \\
\text { clerical }\end{array}$ & 0.67 & 1.01 & 50.75 & 0.25 & 0.75 & 200.00 & 0.69 & 1.33 & 92.75 & 0.69 & 0.85 & 23.19 \\
\hline$\overline{\text { Average }}$ & 0.70 & 0.84 & 20.00 & 0.86 & 0.66 & -23.26 & 0.71 & 0.86 & 21.13 & 0.64 & 0.84 & 31.25 \\
\hline
\end{tabular}




\section{APPENDIX TABLE 22}

Changes in One-Week Per Capita Expenditures of Poultry, July 1973 to July 1975, in West Virginia Population Categories by Occupation of Principal Income Earner

\begin{tabular}{|c|c|c|c|c|c|c|c|c|c|c|c|c|}
\hline \multirow{2}{*}{$\begin{array}{l}\text { Occupation of } \\
\text { Principal } \\
\text { Income Earner }\end{array}$} & \multicolumn{3}{|c|}{ State } & \multicolumn{3}{|c|}{ Rural } & \multicolumn{3}{|c|}{ Middle } & \multicolumn{3}{|c|}{ Urban } \\
\hline & 1973 & 1975 & $\begin{array}{c}\% \\
\text { Change }\end{array}$ & 1973 & 1975 & $\begin{array}{c}\% \\
\text { Change }\end{array}$ & 1973 & 1975 & $\begin{array}{c}\% \\
\text { Change }\end{array}$ & 1973 & 1975 & $\begin{array}{c}\% \\
\text { Change }\end{array}$ \\
\hline Farmer & 0.46 & 1.31 & 184.78 & 0.56 & - & - & 0.30 & 1.31 & 336.67 & - & - & - \\
\hline Professor & 0.67 & 0.89 & 32.84 & 0.83 & 0.92 & 10.84 & 0.72 & 0.85 & 18.06 & 0.64 & 0.93 & 45.31 \\
\hline Housewife & 1.35 & 0.93 & -31.11 & 1.00 & 0.75 & -25.00 & 1.63 & 1.54 & -5.52 & 1.50 & 0.17 & -88.67 \\
\hline Laborer & 0.58 & 0.76 & 31.03 & 0.70 & 0.39 & -44.29 & 0.53 & 0.81 & 52.83 & 0.60 & 0.80 & 33.33 \\
\hline Self-employed & 0.75 & 0.93 & 24.00 & 0.93 & 0.90 & -3.23 & 0.64 & 0.92 & 43.75 & 0.80 & 0.94 & 17.50 \\
\hline Retired & 0.97 & 1.24 & 27.84 & 1.13 & 0.91 & -24.18 & 0.92 & 1.07 & 16.30 & 0.99 & 1.45 & 46.47 \\
\hline Unemployed & 1.05 & 1.00 & -4.76 & 1.13 & - & - & 1.00 & 0.75 & 25.00 & 1.06 & 1.40 & 32.08 \\
\hline White collar & 0.58 & 0.82 & 41.38 & 0.83 & - & - & 0.66 & 0.94 & 42.42 & 0.53 & 0.73 & 37.74 \\
\hline Service worker & 0.81 & 0.58 & -28.40 & 0.90 & - & - & 0.77 & 0.48 & -37.66 & 0.84 & 0.67 & -20.24 \\
\hline Craftsman & 0.71 & 0.79 & 11.27 & 0.37 & - & - & 0.80 & 0.91 & 13.75 & 0.76 & 0.59 & -22.37 \\
\hline Operator & 0.80 & 0.77 & -3.75 & 1.50 & 0.47 & -68.67 & 0.61 & 0.96 & 57.38 & 0.82 & 0.68 & -17.07 \\
\hline $\begin{array}{l}\text { Sales } \\
\text { and Clerical }\end{array}$ & 1.00 & 0.95 & -5.00 & 0.75 & 0.75 & - & 0.85 & 1.30 & 52.94 & 1.17 & 0.78 & -33.33 \\
\hline Average & 0.75 & 0.92 & 22.67 & 0.89 & 0.64 & -28.09 & 0.71 & 0.94 & 32.39 & 0.74 & 0.93 & 25.68 \\
\hline
\end{tabular}


APPENDIX TABLE 23

Changes in One-Week Per Capita Consumption of Seafood, July 1973 to July 1975, in West Virginia Population Categories by Occupation of Principal Income

Earner

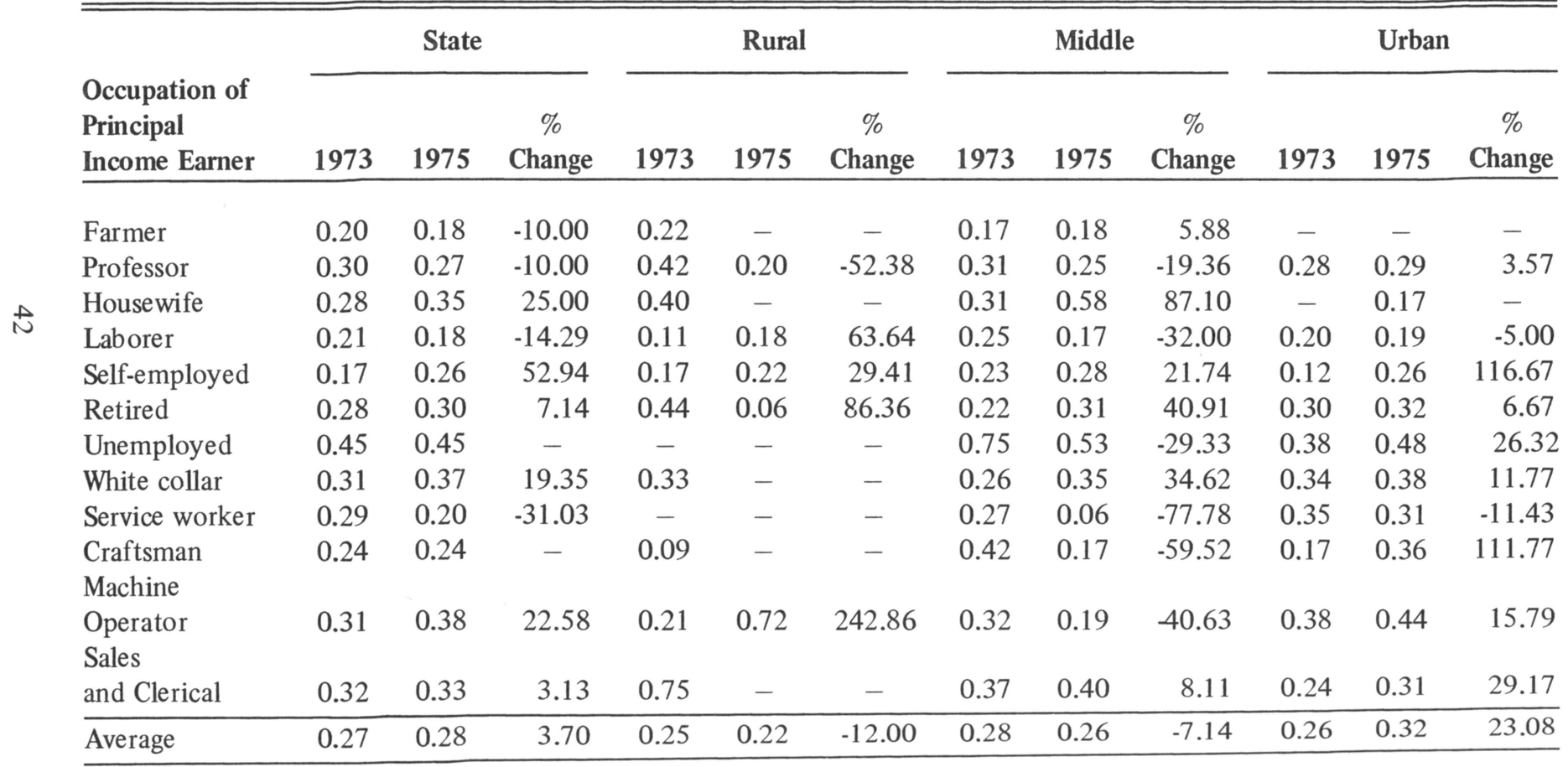


APPENDIX TABLE 24

Changes in One-Week Per Capita Expenditures of Seafood, July 1973 to July 1975,

in West Virginia Population Categories by Occupation of Principal Income Earner

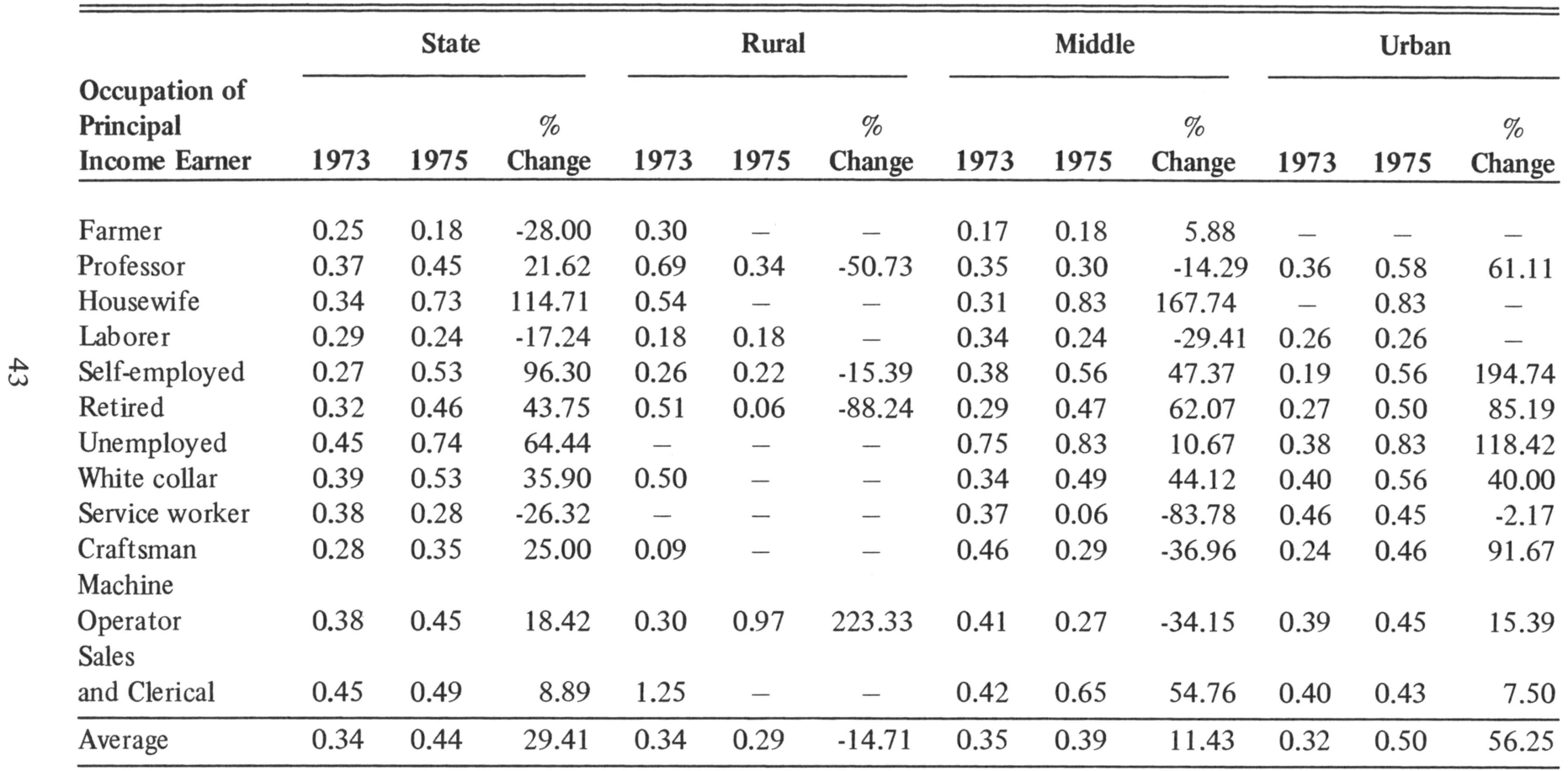




\section{APPENDIX TABLE 25}

Changes in One-Week Per Capita Consumption of Beef, July 1973 to July 1975, in West Virginia Population Categories by Household Size

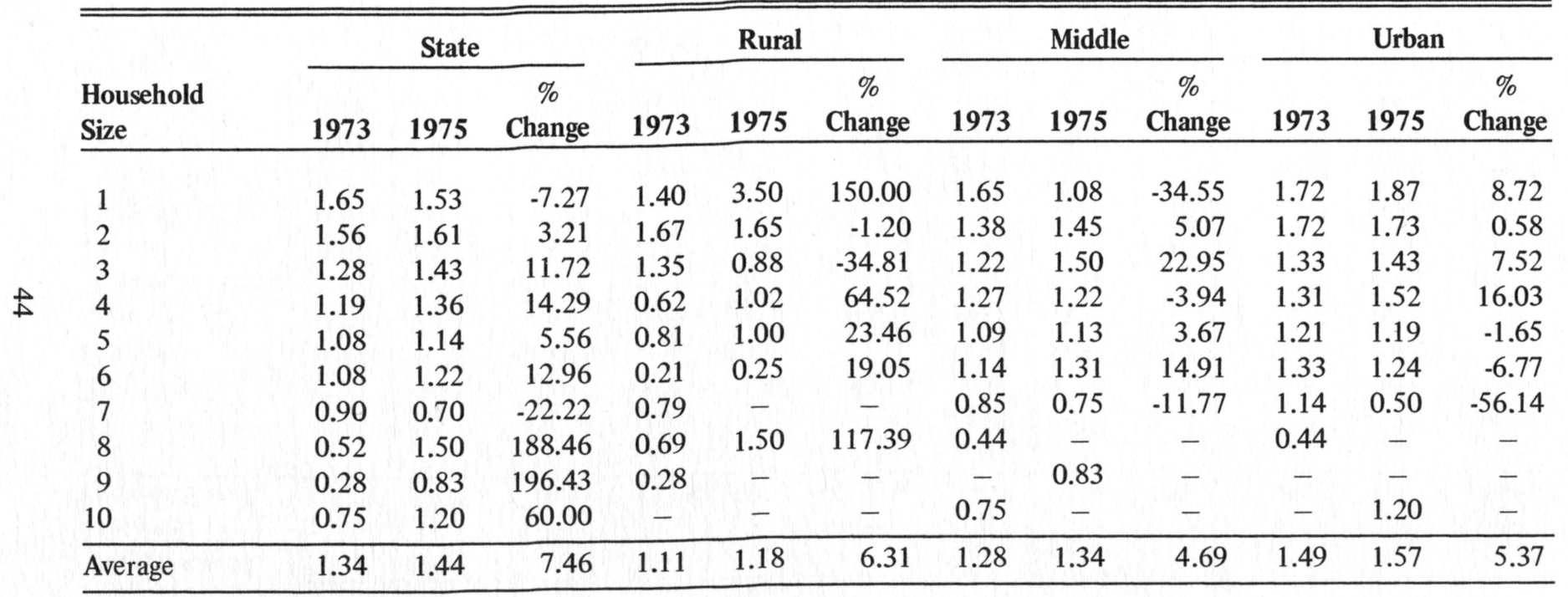


APPENDIX TABLE 26

Changes in One-Week Per Capita Expenditures of Beef, July 1973 to July 1975, in West Virginia Population Categories by Household Size

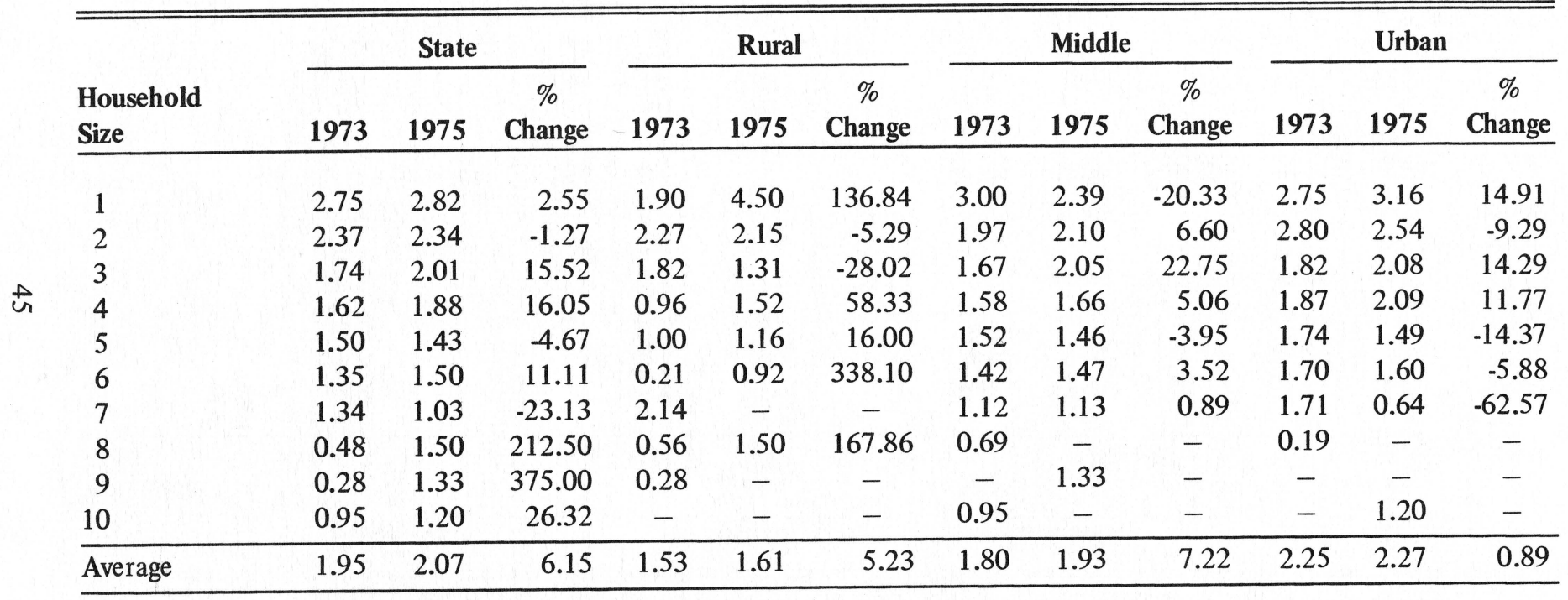




\section{APPENDIX TABLE 27}

Changes in One-Week Per Capita Consumption of Pork, July 1973 to July 1975, in West Virginia Population Categories by Household Size

\begin{tabular}{|c|c|c|c|c|c|c|c|c|c|c|c|c|}
\hline \multirow[b]{2}{*}{$\begin{array}{l}\text { Household } \\
\text { Size } \\
\end{array}$} & \multicolumn{3}{|c|}{ State } & \multicolumn{3}{|c|}{ Rural } & \multicolumn{3}{|c|}{ Middle } & \multicolumn{3}{|c|}{ Urban } \\
\hline & 1973 & 1975 & $\begin{array}{c}\% \\
\text { Change } \\
\end{array}$ & 1973 & 1975 & $\begin{array}{c}\% \\
\text { Change }\end{array}$ & 1973 & 1975 & $\begin{array}{c}\% \\
\text { Change }\end{array}$ & 1973 & 1975 & $\begin{array}{c}\% \\
\text { Change } \\
\end{array}$ \\
\hline 1 & 0.61 & 0.53 & -13.11 & 0.60 & 0.50 & -16.67 & 0.62 & 0.53 & -14.52 & 0.61 & 0.53 & -13.12 \\
\hline 2 & 0.71 & 0.68 & -4.23 & 0.93 & 0.60 & -35.48 & 0.75 & 0.69 & -8.00 & 0.62 & 0.67 & 8.07 \\
\hline 3 & 0.64 & 0.64 & - & 0.79 & 0.43 & -45.57 & 0.66 & 0.73 & 10.61 & 0.55 & 0.53 & -3.64 \\
\hline 4 & 0.51 & 0.54 & 5.88 & 0.63 & 0.52 & -17.46 & 0.52 & 0.56 & 7.69 & 0.46 & 0.52 & 13.04 \\
\hline 5 & 0.47 & 0.54 & 14.89 & 0.45 & 0.66 & 46.67 & 0.61 & 0.54 & -11.48 & 0.28 & 0.52 & 85.71 \\
\hline 6 & 0.57 & 0.45 & -21.05 & 0.54 & 0.25 & -53.70 & 0.57 & 0.56 & -1.75 & 0.58 & 0.35 & -39.66 \\
\hline 7 & 0.58 & 0.74 & 27.59 & 0.64 & - & - & 0.69 & 0.84 & 21.74 & 0.14 & 0.36 & 157.14 \\
\hline 8 & 0.48 & 1.19 & 147.92 & 0.56 & 1.19 & 112.50 & 0.56 & - & - & 0.31 & - & - \\
\hline 9 & 0.94 & 1.33 & 41.49 & 0.94 & - & - & - & 1.33 & - & - & - & - \\
\hline 10 & 0.55 & - & - & - & - & - & 0.55 & - & - & - & - & - \\
\hline Average & 0.61 & 0.61 & - & 0.72 & 0.55 & -23.61 & 0.65 & 0.65 & - & 0.53 & 0.57 & 7.55 \\
\hline
\end{tabular}




\section{APPENDIX TABLE 28}

Changes in One-Week Per Capita Expenditures of Pork, July 1973 to July 1975, in West Virginia Population Categories by Household Size

\begin{tabular}{|c|c|c|c|c|c|c|c|c|c|c|c|c|}
\hline \multirow[b]{2}{*}{$\begin{array}{l}\text { Household } \\
\text { Size } \\
\end{array}$} & \multicolumn{3}{|c|}{ State } & \multicolumn{3}{|c|}{ Rural } & \multicolumn{3}{|c|}{ Middle } & \multicolumn{3}{|c|}{ Urban } \\
\hline & 1973 & 1975 & $\begin{array}{c}\% \\
\text { Change } \\
\end{array}$ & 1973 & 1975 & $\begin{array}{c}\% \\
\text { Change }\end{array}$ & 1973 & 1975 & $\begin{array}{c}\% \\
\text { Change }\end{array}$ & 1973 & 1975 & $\begin{array}{c}\% \\
\text { Change } \\
\end{array}$ \\
\hline 1 & 0.95 & 0.96 & 1.05 & 0.70 & 1.50 & 114.29 & 0.97 & 0.95 & -2.06 & 1.00 & 0.95 & -5.00 \\
\hline 2 & 1.03 & 1.13 & 9.71 & 1.33 & 1.10 & -17.29 & 0.98 & 1.15 & 17.35 & 1.01 & 1.13 & 11.88 \\
\hline 3 & 0.97 & 0.97 & - & 1.15 & 0.86 & -25.22 & 1.03 & 1.08 & 4.85 & 0.81 & 0.79 & -2.47 \\
\hline 4 & 0.74 & 0.82 & 10.81 & 0.74 & 0.81 & 9.46 & 0.75 & 0.78 & 4.00 & 0.74 & 0.85 & 14.87 \\
\hline 5 & 0.63 & 0.80 & 26.98 & 0.60 & 1.04 & 73.33 & 0.77 & 0.82 & 6.49 & 0.44 & 0.71 & 61.36 \\
\hline 6 & 0.78 & 0.64 & -17.95 & 0.71 & 0.58 & -18.31 & 0.77 & 0.71 & -7.79 & 0.82 & 0.57 & -30.49 \\
\hline 7 & 0.74 & 1.10 & 48.65 & 1.71 & - & - & 0.73 & 1.21 & 65.75 & 0.29 & 0.64 & 120.69 \\
\hline 8 & 0.65 & 1.19 & 83.08 & 0.81 & 1.19 & 46.91 & 0.94 & - & - & 0.19 & - & - \\
\hline 9 & 1.67 & 1.66 & -0.60 & 1.67 & - & - & - & 1.67 & - & - & - & - \\
\hline 10 & 0.75 & - & - & - & - & - & 0.75 & - & - & - & - & - \\
\hline$\overline{\text { Average }}$ & 0.89 & 0.96 & 7.87 & 0.99 & 0.96 & -3.0 & 0.91 & 1.00 & 9.89 & 0.84 & 0.93 & 10.71 \\
\hline
\end{tabular}




\section{APPENDIX TABLE 29}

Changes in One-Week Per Capita Consumption of Poultry, July 1973 to July 1975, in West Virginia Population Categories by Household Size

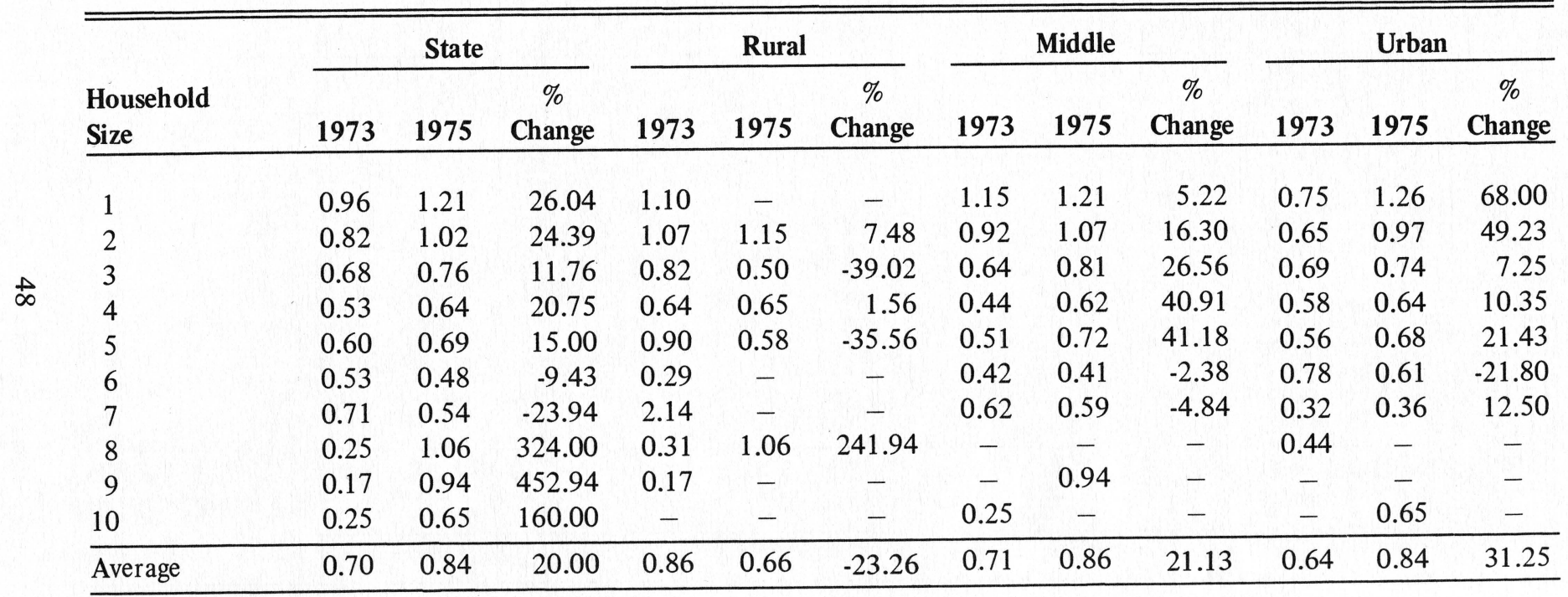




\section{APPENDIX TABLE 30}

Changes in One-Week Per Capita Expenditures of Poultry, July 1973 to July 1975 in West Virginia Population Categories by Household Size

\begin{tabular}{|c|c|c|c|c|c|c|c|c|c|c|c|c|}
\hline \multirow[b]{2}{*}{$\begin{array}{l}\text { Household } \\
\text { Size }\end{array}$} & \multicolumn{3}{|c|}{ State } & \multicolumn{3}{|c|}{ Rural } & \multicolumn{3}{|c|}{ Middle } & \multicolumn{3}{|c|}{ Urban } \\
\hline & 1973 & 1975 & $\begin{array}{c}\% \\
\text { Change } \\
\end{array}$ & 1973 & 1975 & $\begin{array}{c}\% \\
\text { Change } \\
\end{array}$ & 1973 & 1975 & $\begin{array}{c}\% \\
\text { Change }\end{array}$ & 1973 & 1975 & $\begin{array}{c}\% \\
\text { Change }\end{array}$ \\
\hline 1 & 1.33 & 1.78 & 33.84 & 1.40 & - & - & 1.03 & 1.63 & 58.25 & 1.58 & 2.03 & 28.48 \\
\hline 2 & 0.88 & 1.06 & 20.46 & 1.17 & 0.95 & -18.80 & 0.98 & 1.12 & 14.29 & 0.70 & 1.02 & 45.71 \\
\hline 3 & 0.68 & 0.77 & 13.24 & 0.74 & 0.50 & -32.43 & 0.63 & 0.83 & 21.13 & 0.73 & 0.73 & - \\
\hline 4 & 0.55 & 0.66 & 20.00 & 0.70 & 0.77 & 10.00 & 0.47 & 0.67 & 42.55 & 0.58 & 0.63 & 8.62 \\
\hline 5 & 0.55 & 0.68 & 23.64 & 0.74 & 0.54 & -27.03 & 0.51 & 0.76 & 49.02 & 0.53 & 0.64 & 20.76 \\
\hline 6 & 0.52 & 0.51 & -1.92 & 0.29 & - & - & 0.39 & 0.43 & 10.26 & 0.78 & 0.68 & -12.82 \\
\hline 7 & 0.69 & 0.74 & 7.25 & 2.14 & - & - & 0.58 & 0.80 & 37.93 & 0.32 & 0.50 & 56.25 \\
\hline 8 & 0.21 & 1.06 & 404.76 & 0.56 & 1.06 & 89.29 & - & - & - & 0.06 & - & - \\
\hline 9 & 0.28 & 1.06 & 278.57 & 0.28 & - & - & - & 1.06 & - & - & - & - \\
\hline 10 & 0.25 & 0.35 & 40.00 & - & - & - & 0.25 & - & - & - & 0.35 & - \\
\hline Average & 0.75 & 0.92 & 22.67 & 0.89 & 0.64 & -28.09 & 0.71 & 0.94 & 32.39 & 0.74 & 0.93 & 25.68 \\
\hline
\end{tabular}




\section{APPENDIX TABLE 31}

Changes in One-Week Per Capita Consumption of Seafood, July 1973 to July 1975, in West Virginia Population Categories by Household Size

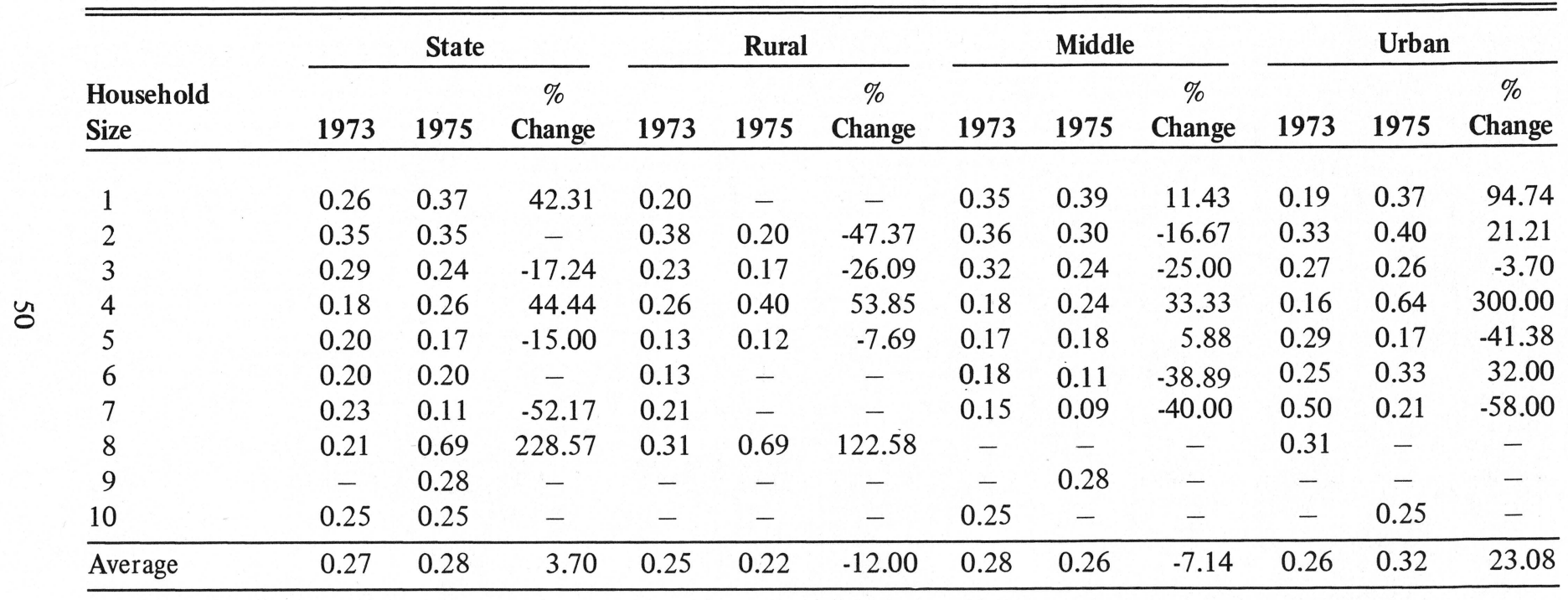

$0.18 \quad 0.11 \quad-38.89$ 


\section{APPENDIX TABLE 32}

Changes in One-Week Per Capita Expenditures of Seafood, July 1973 to July 1975, in West Virginia Population Categories by Household Size

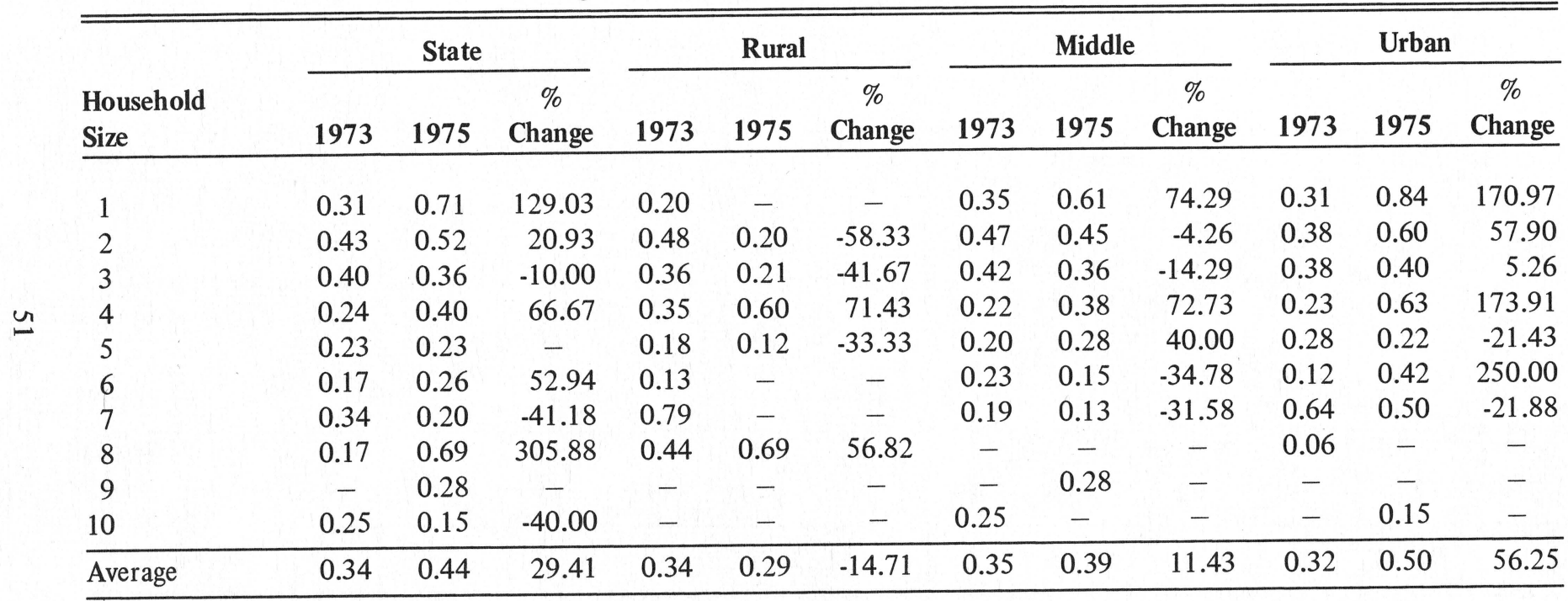




\section{APPENDIX TABLE 34}

Changes in One-Week Per Capita Expenditures for Beef, July 1973 to July 1975, in West Virginia Population Categories by Total Annual Household Income

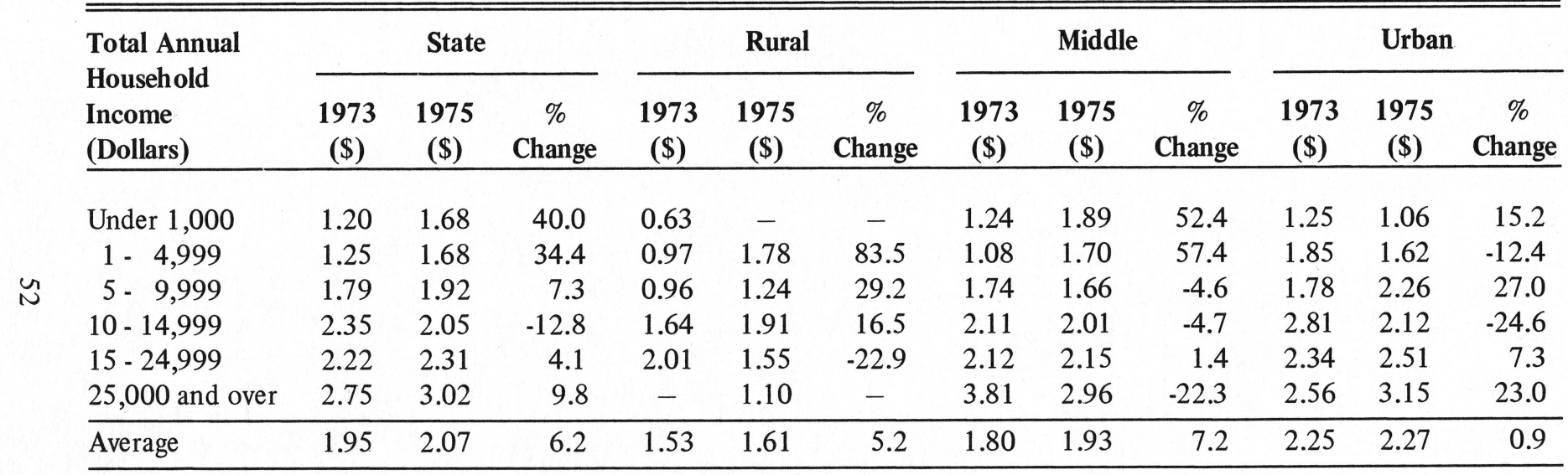




\section{APPENDIX TABLE 33}

Changes in One-Week Per Capita Consumption of Beef, July 1973 to July 1975, in West Virginia Population Categories by Total Annual Household Income

\begin{tabular}{|c|c|c|c|c|c|c|c|c|c|c|c|c|}
\hline \multirow{2}{*}{$\begin{array}{l}\text { Total Annual } \\
\text { Household } \\
\text { Income } \\
\text { (Dollars) } \\
\end{array}$} & \multicolumn{3}{|c|}{ State } & \multicolumn{3}{|c|}{ Rural } & \multicolumn{3}{|c|}{ Middle } & \multicolumn{3}{|c|}{ Urban } \\
\hline & 1973 & 1975 & $\begin{array}{c}\% \\
\text { Change }\end{array}$ & 1973 & 1975 & $\begin{array}{c}\% \\
\text { Change }\end{array}$ & 1973 & 1975 & $\begin{array}{c}\% \\
\text { Change }\end{array}$ & 1973 & 1975 & $\begin{array}{c}\% \\
\text { Change }\end{array}$ \\
\hline Under 1,000 & 1.06 & 1.10 & 3.77 & 0.38 & - & - & 1.08 & 1.08 & - & 1.25 & 1.17 & -6.40 \\
\hline $1-4,999$ & 0.98 & 1.21 & 23.47 & 0.84 & 1.34 & 59.52 & 0.82 & 1.12 & 36.59 & 1.42 & 1.32 & -7.04 \\
\hline $5-9,999$ & 1.28 & 1.36 & 6.25 & 1.29 & 0.91 & -29.46 & 1.27 & 1.15 & -9.45 & 1.29 & 1.61 & 24.81 \\
\hline $10-14,999$ & 1.50 & 1.44 & -4.00 & 1.04 & 1.45 & 39.42 & 1.43 & 1.44 & 0.67 & 1.70 & 1.44 & -15.29 \\
\hline $15-24,999$ & 1.55 & 1.58 & 1.94 & 1.71 & 1.04 & -39.18 & 1.57 & 1.57 & - & 1.51 & 1.62 & 7.29 \\
\hline 25,000 and over & 1.59 & 1.91 & 20.13 & - & 0.70 & - & 1.71 & 1.82 & 6.43 & 1.57 & 2.01 & 28.03 \\
\hline Average & 1.34 & 1.44 & 7.46 & 1.11 & 1.18 & 6.31 & 1.28 & 1.34 & 4.69 & 1.49 & 1.57 & 5.37 \\
\hline
\end{tabular}




\section{APPENDIX TABLE 35}

Changes in One-Week Per Capita Consumption of Pork, July 1973 to July 1975, in West Virginia Population Categories by Total Annual Household Income

\begin{tabular}{|c|c|c|c|c|c|c|c|c|c|c|c|c|}
\hline \multirow{2}{*}{$\begin{array}{l}\text { Total Annual } \\
\text { Household } \\
\text { Income } \\
\text { (Dollars) } \\
\end{array}$} & \multicolumn{3}{|c|}{ State } & \multicolumn{3}{|c|}{ Rural } & \multicolumn{3}{|c|}{ Middle } & \multicolumn{3}{|c|}{ Urban } \\
\hline & 1973 & 1975 & $\begin{array}{c}\% \\
\text { Change } \\
\end{array}$ & 1973 & 1975 & $\begin{array}{c}\% \\
\text { Change } \\
\end{array}$ & 1973 & 1975 & $\begin{array}{c}\% \\
\text { Change } \\
\end{array}$ & 1973 & 1975 & $\begin{array}{c}\% \\
\text { Change } \\
\end{array}$ \\
\hline Under 1,000 & 0.40 & 0.51 & 27.50 & 0.13 & - & - & 0.42 & 0.42 & - & 0.42 & 0.79 & 88.10 \\
\hline 1 - 4,999 & 0.63 & 0.60 & -4.76 & 0.70 & 0.58 & -17.14 & 0.59 & 0.60 & 1.70 & 0.62 & 0.61 & -1.61 \\
\hline $5-9,999$ & 0.61 & 0.60 & -1.64 & 0.79 & 0.68 & -13.92 & 0.63 & 0.64 & 1.59 & 0.50 & 0.56 & 12.00 \\
\hline $10-14,999$ & 0.67 & 0.60 & -10.45 & 0.70 & 0.39 & -44.29 & 0.77 & 0.71 & -7.79 & 0.53 & 0.54 & 1.89 \\
\hline $15-24,999$ & 0.62 & 0.59 & -4.84 & 0.63 & 0.54 & -14.29 & 0.62 & 0.62 & - & 0.61 & 0.56 & 8.20 \\
\hline 25,000 and over & 0.41 & 0.65 & 58.54 & - & 0.90 & - & 0.56 & 0.71 & 26.79 & 0.38 & 0.62 & 63.16 \\
\hline Average & 0.61 & 0.61 & - & 0.72 & 0.55 & -23.61 & 0.65 & 0.65 & - & 0.53 & 0.57 & 7.55 \\
\hline
\end{tabular}


APPENDIX TABLE 36

Changes in One-Week Per Capita Expenditures for Pork, July 1973 to July 1975, in West Virginia Population Categories by Total Annual Household Income

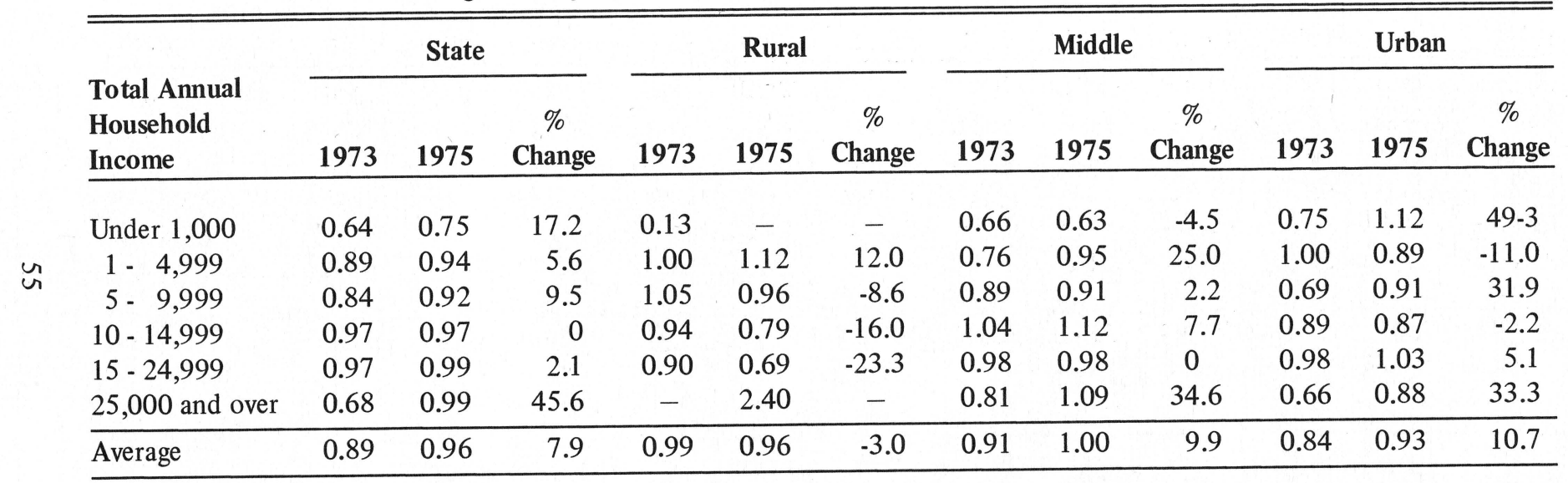




\section{APPENDIX TABLE 37}

Changes in One-Week Per Capita Consumption of Poultry, July 1973 to July 1975, in West Virginia Population Categories by Total Annual Household Income

\begin{tabular}{|c|c|c|c|c|c|c|c|c|c|c|c|c|}
\hline \multirow{2}{*}{$\begin{array}{l}\text { Total Annual } \\
\text { Household } \\
\text { Income } \\
\text { (Dollars) } \\
\end{array}$} & \multicolumn{3}{|c|}{ State } & \multicolumn{3}{|c|}{ Rural } & \multicolumn{3}{|c|}{ Middle } & \multicolumn{3}{|c|}{ Urban } \\
\hline & 1973 & 1975 & $\begin{array}{c}\% \\
\text { Change }\end{array}$ & 1973 & 1975 & $\begin{array}{c}\% \\
\text { Change }\end{array}$ & 1973 & 1975 & $\begin{array}{c}\% \\
\text { Change }\end{array}$ & 1973 & 1975 & $\begin{array}{c}\% \\
\text { Change } \\
\end{array}$ \\
\hline Under 1,000 & 0.39 & 0.66 & 69.23 & 0.13 & - & - & 0.41 & 0.47 & 14.63 & 0.42 & 1.23 & 192.86 \\
\hline $1-4,999$ & 0.75 & 0.96 & 28.00 & 0.78 & 0.63 & 19.23 & 0.85 & 0.98 & 15.29 & 0.55 & 1.01 & 83.64 \\
\hline $5-9,999$ & 0.77 & 0.87 & 12.99 & 1.11 & 0.87 & -21.62 & 0.64 & 0.88 & 37.50 & 0.79 & 0.85 & 7.60 \\
\hline $10-14,999$ & 0.66 & 0.76 & 15.15 & 0.38 & 0.47 & 23.68 & 0.73 & 0.76 & 4.11 & 0.62 & 0.81 & 30.65 \\
\hline $15-24,999$ & 0.66 & 0.86 & 30.30 & 1.07 & 0.82 & -23.36 & 0.68 & 0.90 & 32.35 & 0.59 & 0.82 & 38.98 \\
\hline 25,000 and over & 0.65 & 0.80 & 23.08 & - & 0.30 & - & 1.08 & 1.20 & 11.11 & 0.58 & 0.68 & 17.24 \\
\hline Average & 0.70 & 0.84 & 20.00 & 0.86 & 0.66 & -23.26 & 0.71 & 0.86 & 21.13 & 0.64 & 0.84 & 31.25 \\
\hline
\end{tabular}




\section{APPENDIX TABLE 38}

Changes in One-Week Per Capita Expenditures of Poultry, July 1973 to July 1975, in West Virginia Population Categories by Total Annual Household Income

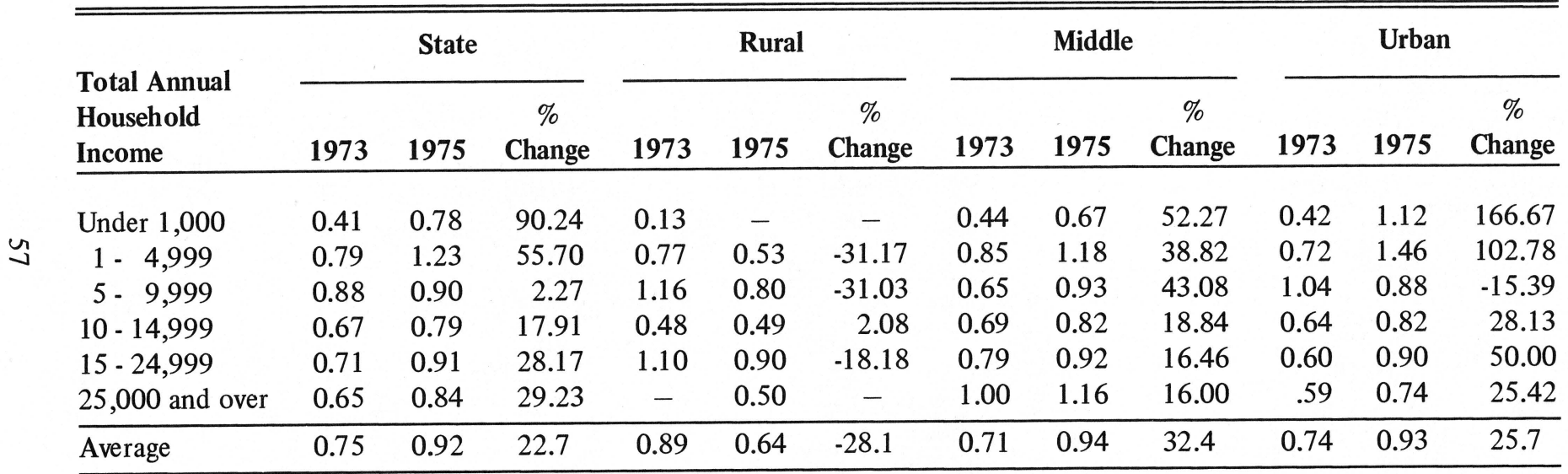




\section{APPENDIX TABLE 39}

Changes in One-Week Per Capita Consumption of Seafood, July 1973 to July 1975, in West Virginia Population Categories by Total Annual Household Income

\begin{tabular}{|c|c|c|c|c|c|c|c|c|c|c|c|c|}
\hline \multirow{2}{*}{$\begin{array}{l}\text { Total Annual } \\
\text { Household } \\
\text { Income } \\
\text { (Dollars) } \\
\end{array}$} & \multicolumn{3}{|c|}{ State } & \multicolumn{3}{|c|}{ Rural } & \multicolumn{3}{|c|}{ Middle } & \multicolumn{3}{|c|}{ Urban } \\
\hline & 1973 & 1975 & $\begin{array}{c}\% \\
\text { Change }\end{array}$ & 1973 & 1975 & $\begin{array}{c}\% \\
\text { Change } \\
\end{array}$ & 1973 & 1975 & $\begin{array}{c}\% \\
\text { Change }\end{array}$ & 1973 & 1975 & $\begin{array}{c}\% \\
\text { Change }\end{array}$ \\
\hline Under 1,000 & 0.11 & 0.38 & 245.45 & 0.63 & - & - & 0.09 & 0.43 & 377.78 & - & 0.22 & - \\
\hline $1-4,999$ & 0.22 & 0.22 & - & 0.22 & 0.15 & -31.82 & 0.15 & 0.17 & 13.33 & 0.35 & 0.32 & -8.57 \\
\hline $5-9,999$ & 0.28 & 0.30 & 7.14 & 0.27 & 0.22 & -18.52 & 0.30 & 0.32 & 6.67 & 0.25 & 0.28 & 12.00 \\
\hline $10-14,999$ & 0.25 & 0.29 & 16.00 & 0.08 & 0.29 & 262.50 & 0.31 & 0.23 & -25.81 & 0.20 & 0.35 & 75.00 \\
\hline 15 - 24,999 & 0.33 & 0.30 & -9.09 & 0.50 & 0.21 & -58.00 & 0.37 & 0.23 & -37.84 & 0.27 & 0.37 & 37.04 \\
\hline 25,000 and over & 0.36 & 0.23 & -36.11 & - & 0.10 & - & 0.54 & 0.26 & -51.85 & 0.33 & 0.22 & -33.33 \\
\hline Average & 0.27 & 0.28 & 3.70 & 0.25 & 0.22 & -12.00 & 0.28 & 0.26 & -7.14 & 0.26 & 0.32 & 23.08 \\
\hline
\end{tabular}




\section{APPENDIX TABLE 40}

Changes in One-Week Per Capita Expenditures of Seafood, July 1973 to July 1975, in West Virginia Population Categories by Total Annual Household Income

\begin{tabular}{|c|c|c|c|c|c|c|c|c|c|c|c|c|}
\hline \multirow{2}{*}{$\begin{array}{l}\text { Total Annual } \\
\text { Household } \\
\text { Income } \\
\text { (Dollars) }\end{array}$} & \multicolumn{3}{|c|}{ State } & \multicolumn{3}{|c|}{ Rural } & \multicolumn{3}{|c|}{ Middle } & \multicolumn{3}{|c|}{ Urban } \\
\hline & 1973 & 1975 & $\begin{array}{c}\% \\
\text { Change }\end{array}$ & 1973 & 1975 & $\begin{array}{c}\% \\
\text { Change }\end{array}$ & 1973 & 1975 & $\begin{array}{c}\% \\
\text { Change }\end{array}$ & 1973 & 1975 & $\begin{array}{c}\% \\
\text { Change }\end{array}$ \\
\hline Under 1,000 & 0.11 & 0.44 & 300.00 & 0.63 & - & - & 0.09 & 0.51 & 466.67 & - & 0.22 & - \\
\hline $1-4,999$ & 0.24 & 0.37 & 54.17 & 0.30 & 0.15 & -50.00 & 0.18 & 0.29 & 61.11 & 0.31 & 0.54 & 74.19 \\
\hline $5-9,999$ & 0.33 & 0.41 & 24.24 & 0.39 & 0.22 & -43.59 & 0.38 & 0.46 & 21.05 & 0.26 & 0.39 & 50.00 \\
\hline $10-14,999$ & 0.33 & 0.42 & 27.27 & 0.19 & 0.44 & 131.58 & 0.38 & 0.31 & -18.42 & 0.28 & 0.52 & 85.71 \\
\hline $15-24,999$ & 0.43 & 0.50 & 16.28 & 0.56 & 0.29 & -48.21 & 0.49 & 0.38 & -22.45 & 0.36 & 0.63 & 75.00 \\
\hline 25,000 and over & 0.52 & 0.44 & -15.39 & - & 0.10 & - & 0.67 & 0.36 & -46.27 & 0.50 & 0.48 & -4.00 \\
\hline Average & 0.34 & 0.44 & 29.4 & 0.34 & 0.29 & -14.7 & 0.35 & 0.39 & 11.4 & 0.32 & 0.50 & 56.3 \\
\hline
\end{tabular}


APPENDIX TABLE 41

Number of Responses and Per Cent of Households Responding by Socioeconomic Categories, Summer 1975

\begin{tabular}{|c|c|c|c|c|c|c|c|c|}
\hline \multirow{2}{*}{$\begin{array}{l}\text { Socioeconomic Category } \\
\text { Family Member Most } \\
\text { Responsible for } \\
\text { Meat Purchasing }\end{array}$} & \multicolumn{2}{|c|}{ State } & \multicolumn{2}{|c|}{ Rural } & \multicolumn{2}{|c|}{ Middle } & \multicolumn{2}{|c|}{ Urban } \\
\hline & $\begin{array}{c}\text { Respon- } \\
\text { sible }\end{array}$ & $\%$ & $\begin{array}{c}\text { Respon- } \\
\text { sible }\end{array}$ & $\%$ & $\begin{array}{c}\text { Respon- } \\
\text { sible }\end{array}$ & $\%$ & $\begin{array}{c}\text { Respon- } \\
\text { sible }\end{array}$ & $\%$ \\
\hline Wife & 270 & 64.29 & 18 & 69.23 & 131 & 66.50 & 121 & 61.42 \\
\hline Husband & 77 & 18.33 & 5 & 19.23 & 30 & 15.23 & 42 & 21.32 \\
\hline Single & 53 & 12.62 & 2 & 7.69 & 29 & 14.72 & 22 & 11.17 \\
\hline Both wife and husband & 19 & 4.52 & 1 & 3.85 & 6 & 3.05 & 12 & 6.09 \\
\hline 0 & 1 & 0.24 & - & - & 1 & 0.51 & - & - \\
\hline Total & 420 & 100.00 & 26 & 100.00 & 197 & 100.00 & 197 & 100.00 \\
\hline \multicolumn{9}{|l|}{$\begin{array}{l}\text { Principal } \\
\text { Income Earner }\end{array}$} \\
\hline Wife & 27 & 6.43 & 2 & 7.69 & 10 & 5.08 & 15 & 7.61 \\
\hline Husband & 309 & 73.57 & 22 & 84.62 & 143 & 72.59 & 144 & 73.10 \\
\hline Single & 55 & 13.10 & 2 & 7.69 & 29 & 14.72 & 24 & 12.18 \\
\hline Joint & 29 & 6.91 & - & - & 15 & 7.61 & 14 & 7.11 \\
\hline Total & 420 & 100.00 & 26 & 100.00 & 197 & 100.00 & 197 & 100.00 \\
\hline
\end{tabular}


Age of Principal

Income Earner

\begin{tabular}{lrrrrrrrr} 
Under 25 & 13 & 3.10 & 1 & 3.85 & 4 & 2.03 & 8 & 4.06 \\
$25-34$ & 84 & 20.00 & 8 & 30.77 & 42 & 21.32 & 34 & 17.26 \\
$35-44$ & 57 & 13.57 & 5 & 19.23 & 23 & 11.68 & 29 & 14.72 \\
$45-54$ & 103 & 24.52 & 5 & 19.23 & 50 & 25.38 & 48 & 24.37 \\
$55-64$ & 97 & 23.10 & 3 & 11.54 & 45 & 22.84 & 49 & 24.87 \\
65 and over & 66 & 15.71 & 4 & 15.39 & 33 & 16.75 & 29 & 14.72 \\
\hline Total & 420 & 100.00 & 26 & 100.00 & 197 & 100.00 & 197 & 100.00
\end{tabular}

Education of

Principal

I Income Earner

\begin{tabular}{lrrrrrrrr}
$0-7$ & 38 & 9.05 & 3 & 11.54 & 22 & 11.17 & 13 & 6.60 \\
8 & 49 & 11.67 & 3 & 11.54 & 29 & 14.72 & 17 & 8.63 \\
$9-11$ & 41 & 9.76 & 5 & 19.23 & 25 & 12.69 & 11 & 5.84 \\
12 & 156 & 37.14 & 11 & 42.31 & 62 & 31.47 & 83 & 42.13 \\
$13-15$ & 62 & 14.76 & 3 & 11.54 & 24 & 12.18 & 85 & 17.77 \\
16 & 30 & 7.14 & - & - & 16 & 8.12 & 14 & 7.12 \\
Over 16 & 42 & 10.00 & 1 & 3.85 & 17 & 8.63 & 24 & 12.18 \\
0 & 2 & 0.48 & - & - & 2 & 1.02 & - & - \\
\hline Total & 420 & 100.00 & 26 & 100.00 & 197 & 100.00 & 197 & 100.00 \\
\hline
\end{tabular}


Appendix Table 41 (continued)

\begin{tabular}{|c|c|c|c|c|c|c|c|c|}
\hline \multirow{2}{*}{$\begin{array}{l}\text { Socioeconomic Category } \\
\text { Family Member Most } \\
\text { Respondible for } \\
\text { Meat Purchasing } \\
\end{array}$} & \multicolumn{2}{|c|}{ State } & \multicolumn{2}{|c|}{ Rural } & \multicolumn{2}{|c|}{ Middle } & \multicolumn{2}{|c|}{ Urban } \\
\hline & $\begin{array}{l}\text { Respon- } \\
\text { sible }\end{array}$ & $\%$ & $\begin{array}{l}\text { Respon- } \\
\text { sible }\end{array}$ & $\%$ & $\begin{array}{c}\text { Respon- } \\
\text { sible }\end{array}$ & $\%$ & $\begin{array}{l}\text { Respon- } \\
\text { sible }\end{array}$ & $\%$ \\
\hline \multicolumn{9}{|l|}{$\begin{array}{l}\text { Occupation } \\
\text { of Principal } \\
\text { Income Earner }\end{array}$} \\
\hline No response & 5 & 1.19 & 1 & 3.85 & 1 & 0.51 & 3 & 1.52 \\
\hline Farmer & 5 & 1.19 & - & - & 5 & 2.54 & - & - \\
\hline Professor & 60 & 14.29 & 4 & 15.39 & 24 & 12.18 & 32 & 16.24 \\
\hline Housewife & 8 & 1.91 & 1 & 3.85 & 4 & 2.03 & 3 & 1.52 \\
\hline Laborer & 62 & 14.76 & 7 & 26.92 & 34 & 17.26 & 21 & 10.66 \\
\hline Self-employed & 38 & 9.05 & 3 & 11.54 & 20 & 10.15 & 15 & 7.61 \\
\hline Retired & 81 & 19.29 & 4 & 15.39 & 39 & 19.80 & 38 & 19.29 \\
\hline Unemployed & 10 & 2.38 & 1 & 3.85 & 4 & 2.03 & 5 & 2.54 \\
\hline White collar & 49 & 11.67 & - & - & 20 & 10.15 & 29 & 14.72 \\
\hline Service worker & 18 & 4.29 & - & - & 8 & 4.06 & 10 & 5.08 \\
\hline Craftsman & 25 & 5.95 & - & - & 16 & 8.12 & 9 & 4.57 \\
\hline Machine operator & 29 & 6.91 & 4 & 15.39 & 12 & 6.09 & 13 & 6.60 \\
\hline Sales and clerical & 30 & 7.14 & 1 & 3.85 & 10 & 5.08 & 19 & 9.65 \\
\hline Total & 420 & 100.00 & 26 & 100.00 & 197 & 100.00 & 197 & 100.00 \\
\hline \multicolumn{9}{|l|}{$\begin{array}{l}\text { Household Size } \\
\text { of Principal } \\
\text { Income Earner }\end{array}$} \\
\hline $\begin{array}{l}1 \\
2\end{array}$ & $\begin{array}{r}39 \\
139\end{array}$ & $\begin{array}{r}9.29 \\
33.10\end{array}$ & $\begin{array}{l}1 \\
5\end{array}$ & $\begin{array}{r}3.85 \\
19.23\end{array}$ & $\begin{array}{l}19 \\
60\end{array}$ & $\begin{array}{r}9.65 \\
30.46\end{array}$ & $\begin{array}{l}19 \\
74\end{array}$ & .9 .65 \\
\hline
\end{tabular}




\begin{tabular}{rrrrrrrrr}
3 & 89 & 21.19 & 7 & 26.29 & 52 & 26.40 & 30 & 15.23 \\
4 & 86 & 20.48 & 6 & 23.08 & 34 & 17.26 & 46 & 23.35 \\
5 & 41 & 9.76 & 5 & 19.23 & 18 & 9.14 & 18 & 9.14 \\
6 & 18 & 4.29 & 1 & 3.85 & 9 & 4.57 & 8 & 4.06 \\
7 & 5 & 1.19 & - & - & 4 & 2.03 & 1 & 0.51 \\
8 & 1 & 0.24 & 1 & 3.85 & - & - & - & - \\
9 & 1 & 0.24 & - & - & 1 & 0.51 & - & - \\
10 & 1 & 0.24 & - & - & - & - & 1 & 0.51 \\
\hline Total & 420 & 100.00 & 26 & 100.00 & 197 & 100.00 & 197 & 100.00 \\
\hline
\end{tabular}

Income of

Principal

Income Earner

\begin{tabular}{|c|c|c|c|c|c|c|c|c|}
\hline Under $\$ 1,000$ & 12 & 2.86 & - & - & 9 & 4.57 & 3 & 1.52 \\
\hline $1-4,999$ & 60 & 14.29 & 5 & 19.23 & 33 & 16.75 & 22 & 11.17 \\
\hline $5-9,999$ & 122 & 29.05 & 8 & 30.77 & 55 & 27.92 & 59 & 29.95 \\
\hline $10-14,999$ & 106 & 25.24 & 9 & 34.62 & 46 & 23.35 & 51 & 25.89 \\
\hline $15-24,999$ & 88 & 20.95 & 3 & 11.54 & 43 & 21.83 & 42 & 21.32 \\
\hline Over 25,000 & 26 & 6.19 & 1 & 3.85 & 7 & 3.55 & 18 & 9.14 \\
\hline No response & 6 & 1.43 & - & - & 4 & 2.03 & 2 & 1.02 \\
\hline$\overline{\text { Total }}$ & 420 & 100.00 & 26 & 100.00 & 197 & 100.00 & 197 & 100.00 \\
\hline
\end{tabular}

Consumption

Last Two Years

\begin{tabular}{lrrrrrrrr} 
Increased & 57 & 13.57 & 2 & 7.69 & 32 & 16.24 & 23 & 11.68 \\
Decreased & 163 & 38.81 & 10 & 38.46 & 79 & 40.10 & 74 & 37.56 \\
Same & 197 & 49.91 & 14 & 53.85 & 85 & 43.15 & 98 & 49.75 \\
No response & 3 & 0.71 & - & - & 1 & 0.51 & 2 & 1.02 \\
\hline Total & 420 & 100.00 & 26 & 100.00 & 197 & 100.00 & 197 & 100.00 \\
\hline
\end{tabular}




\section{CONFIDENTIAL \\ Questionnaire \\ West Virginia University \\ Department of Agricultural Economics}

1. Which family member is most responsible for meat purchasing?

( ) Wife

( ) Husband

( ) Other (write in)

2. Which family member is the principal income earner?

( ) Wife

( ) Husband

( ) Other (write in)

3. Age of the principal income earner.

( ) Under 25

( ) $25 \cdot 34$

( ) $35-44$

( ) $45-54$

( ) $55-64$

( ) 65 and over

4. Grade completed in school of the principal income earner.

( ) 0 to 7 years

( ) 8 years (grade school graduate)

( ) 9 to 11 years

( ) 12 years (high school graduate)

( ) 13 to 15 years

( ) 16 years (college graduate)

( ) more than 16 years

5. Occupation of the principal income earner.

( ) Farmer

( ) Professional

( ) Housewife

( ) Laborer
( ) Self-employed

( ) Retired

( ) Unemployed

( ) White Collar
( ) Service worker

( ) Craftsman

( ) Machine Operator

( ) Sales \& Clerical

6. How many people (total number) are there living in your household?
( ) 1
( ) 4
( ) 2
( ) 5
( ) 7
( ) 3
( ) 6
( ) 8
( ) more than 8 (write in) 
7. Into which of the following groups would your total annual household income fail (all family members)?
( ) Under $\$ 1,000$
( ) $\$ 10,000$ to $\$ 14,999$
( ) $\$ 1,000$ to $\$ 4,999$
( ) $\$ 15,000$ to $\$ 24,999$
( ) $\$ 5,000$ to $\$ 9,999$
( ) $\$ 25,000$ and over

8. Has your consumption of meat changed over the last two years?
( ) Increased
( ) Decreased
( ) Same (no change)

9. Which county do you live in?

\section{West Virginia University Department of Agricultural Economics}

We need a complete report on the meats you and your household purchased at retail stores and ate during the last seven days or will eat during the next seven days from the time you receive this questionnaire. The quantity and current price of meats consumed from home freezers should be included. Do not include quantities or prices of meats consumed in restaurants.

If you should encounter any difficulty in deciding which category various types of meats fall, then look at the list that follows.

\section{MEATS}

Beef Steak, roast, stewing, ground, canned, corned, chipped, dried, and other.

Pork Bacon, chops, ham, loin, sausage, salt pork, chipped, dried, and other.

Poultry Chicken, turkey, duck, and other.

Lamb lamb chops, leg of lamb, shoulder roasts, shoulder chops, mutton, and other.

Seafood Fresh, canned, shellfish, and other.

Lunchmeats Bologna, salami, pickle loaf, goose liver, Spam, and other. 


\section{BEEF Eaten Per Week}

( ) 0 to 1 pound

( ) 1 to 2 pounds

( ) 2 to 3 poonds

( ) 3 to 4 pounds

( ) 4 to 5 pounds

( ) 5 to 6 pounds

( ) 6 to 7 pounds

( ) 7 to 8 pounds

( ) 8 to 9 pounds

( ) 9 to 10 pounds

( ) 10 to 14 pounds

( ) 15 pounds and over

PORK Eaten Per Week

( ) 0 to 1 pound

( ) 1 to 2 pounds

( ) 2 to 3 pounds

( ) 3 to 4 pounds

( ) 4 to 5 pounds

( ) 5 to 6 pounds

( ) 6 to 7 pounds

( ) 7 to 8 pounds

( ) 8 to 9 pounds

( ) 9 to 10 pounds

( ) 10 to 14 pounds

( ) 15 pounds and over

POULTRY Eaten Per Week

( ) 0 to 1 pound

( ) 1 to 2 pounds

( ) 2 to 3 pounds

( ) 3 to 4 pounds

( ) 4 to 5 pounds

( ) 5 to 6 pounds

( ) 6 to 7 pounds

( ) 7 to 8 pounds

( ) 8 to 9 pounds

( ) 9 to 10 pounds

( ) 10 to 14 pounds

( ) 15 pounds and over
Total Amount Spent Per Week

( ) 0 to $\$ .99$

( ) $\$ 1.00$ to $\$ 1.99$

( ) $\$ 2.00$ to $\$ 2.99$

( ) $\$ 3.00$ to $\$ 3.99$

( ) $\$ 4.00$ to $\$ 4.99$

( ) $\$ 5.00$ to $\$ 5.99$

( ) $\$ 6.00$ to $\$ 6.99$

( ) $\$ 7.00$ to $\$ 7.99$

( ) $\$ 8.00$ to $\$ 8.99$

( ) $\$ 9.00$ to $\$ 9.99$

( ) $\$ 10.00$ to $\$ 14.99$

( ) $\$ 15.00$ and over

Total Amount Spent Per Week

( ) 0 to $\$ .99$

( ) $\$ 1.00$ to $\$ 1.99$

( ) $\$ 2.00$ to $\$ 2.99$

( ) $\$ 3.00$ to $\$ 3.99$

( ) $\$ 4.00$ to $\$ 4.99$

( ) $\$ 5.00$ to $\$ 5.99$

( ) $\$ 6.00$ to $\$ 6.99$

( ) $\$ 7.00$ to $\$ 7.99$

( ) $\$ 8.00$ to $\$ 8.99$

( ) $\$ 9.00$ to $\$ 9.99$

( ) $\$ 10.00$ to $\$ 14.99$

( ) $\$ 15.00$ and over

Total Amount Spent Per Week

( ) 0 to $\$ .99$

( ) $\$ 1.00$ to $\$ 1.99$

( ) $\$ 2.00$ to $\$ 2.99$

( ) $\$ 3.00$ to $\$ 3.99$

( ) $\$ 4.00$ to $\$ 4.99$

( ) $\$ 5.00$ to $\$ 5.99$

( ) $\$ 6.00$ to $\$ 6.99$

( ) $\$ 7.00$ to $\$ 7.99$

( ) $\$ 8.00$ to $\$ 8.99$

( ) $\$ 9.00$ to $\$ 9.99$

( ) $\$ 10.00$ to $\$ 14.99$

( ) $\$ 15.00$ and over 
LAMB Eaten Per Week

( ) 0 to 1 pound

( ) 1 to 2 pounds

( ) 2 to 3 pounds

( ) 3 to 4 pounds

( ) 4 to 5 pounds

( ) 5 to 6 pounds

( ) 6 to 7 pounds

( ) 7 to 8 pounds

( ) 8 to 9 pounds

( ) 9 to 10 pounds

( ) 10 to 14 pounds

( ) 15 pounds and over

\section{SEAFOOD Eaten Per Week}

( ) 0 to 1 pound

( ) 1 to 2 pounds

( ) 2 to 3 pounds

( ) 3 to 4 pounds

( ) 4 to 5 pounds

( ) 5 to 6 pounds

( ) 6 to 7 pounds

( ) 7 to 8 pounds

( ) 8 to 9 pounds

( ) 9 to 10 pounds

( ) 10 to 14 pounds

( ) 15 pounds and over

\section{LUNCHMEAT Eaten Per Week}

\section{( ) 0 to 1 pound}

( ) 1 to 2 pounds

( ) 2 to 3 pounds

( ) 3 to 4 pounds

( ) 4 to 5 pounds

( ) 5 to 6 pounds

( ) 6 to 7 pounds

( ) 7 to 8 pounds

( ) 8 to 9 pounds

( ) 9 to 10 pounds

( ) 10 to 14 pounds

( ) 15 pounds and over

\section{Total Amount Spent Per Week}

( ) 0 to $\$ .99$

( ) $\$ 1.00$ to $\$ 1.99$

( ) $\$ 2.00$ to $\$ 2.99$

( ) $\$ 3.00$ to $\$ 3.99$

( ) $\$ 4.00$ to $\$ 4.99$

( ) $\$ 5.00$ to $\$ 5.99$

( ) $\$ 6.00$ to $\$ 6.99$

( ) $\$ 7.00$ to $\$ 7.99$

( ) $\$ 8.00$ to $\$ 8.99$

( ) $\$ 9.00$ to $\$ 9.99$

( ) $\$ 10.00$ to $\$ 14.99$

( ) $\$ 15.00$ and over

\section{Total Amount Spent Per Week}

( ) 0 to $\$ .99$

( ) $\$ 1.00$ to $\$ 1.99$

( ) $\$ 2.00$ to $\$ 2.99$

( ) $\$ 3.00$ to $\$ 3.99$

( ) $\$ 4.00$ to $\$ 4.99$

( ) $\$ 5.00$ to $\$ 5.99$

( ) $\$ 6.00$ to $\$ 6.99$

( ) $\$ 7.00$ to $\$ 7.99$

( ) $\$ 8.00$ to $\$ 8.99$

( ) $\$ 9.00$ to $\$ 9.99$

( ) $\$ 10.00$ to $\$ 14.99$

( ) $\$ 15.00$ and over

Total Amount Spent Per Week

( ) 0 to $\$ .999$

( ) $\$ 1.00$ to $\$ 1.99$

( ) $\$ 2.00$ to $\$ 2.99$

( ) $\$ 3.00$ to $\$ 3.99$

( ) $\$ 4.00$ to $\$ 4.99$

( ) $\$ 5.00$ to $\$ 5.99$

( ) $\$ 6.00$ to $\$ 6.99$

( ) $\$ 7.00$ to $\$ 7.99$

( ) $\$ 8.00$ to $\$ 8.99$

( ) $\$ 9.00$ to $\$ 9.99$

( ) $\$ 10.00$ to $\$ 14.99$

( ) $\$ 15.00$ and over 
If you and your household do not use meat in any form, then put a check mark in the blank below.

None

Remarks: 
Blank Page in Original Bulletin 